\title{
Alcoolismo: acusação ou diagnóstico?
}

\author{
Alcoholism: indictment or diagnosis?
}

\author{
1 Programa de Pós-graduação \\ em Antropologia Social \\ e Ciência Política, \\ Universidade Federal \\ Fluminense, Niterói, Brasil. \\ Correspondência \\ Delma Pessanha Neves \\ Programa de Pós-graduação \\ em Antropologia Social \\ e Ciência Política, \\ Universidade Federal \\ Fluminense. Campus do \\ Gragoatá, Bloco O, Sala 301, \\ Niterói, RJ 24120-350, Brasil. \\ mdebes@provide.psi.br
}

\begin{abstract}
This article presents reflections on how alcohol consumption is conceived as a sociological object, including proscribed forms linked to the definition of diseases or disregard for moral norms. Through considerations on the accumulated investment in a research process currently under way, the author highlights the ethical and epistemological dilemmas faced by anthropologists who focus on this issue.

Alcoholism; Alcohol Drinking; Alcohol-Related Disorders; Sociology
\end{abstract}

Delma Pessanha Neves 1

Nas ciências sociais, tem-se acompanhado com vigor uma série de situações qualificadas como problemas sociais contemporâneos, como os decorrentes da presença da AIDS, do uso de drogas ilícitas, da violência especialmente urbana. Mas tem-se dado menor peso ao uso definido como problemático de bebidas alcoólicas. Talvez pela poluição de perspectivas definidoras que articulam tais usos a uma definição de morbidade, especialmente psiquiátrica. Constituindo-se em problema a partir da confluência de domínios biológicos, psicológicos e sociais, a análise do uso "patológico" de bebidas alcoólicas exige investimentos exegéticos e reflexões metodológicas sistemáticas, de modo a ser construído como objeto sociológico.

O carrefour de definições (biológicas, psicológicas e sociológicas) não teria em si razão para se constituir em limitações de difícil transposição, pois que as ciências sociais têm acumulado saber sobre tais ambigüidades. O domínio da sociologia foi construído pela depuração de tais labirintos de perspectivas. Refirome aos investimentos metodológicos deixados por Durkheim 1, ao estabelecer que o suicídio poderia ser estudado enquanto fenômeno social. Contudo, o empenho em demarcar fronteiras disciplinares, ao mesmo tempo que consagrou o reconhecimento de objetos sociológicos, fragmentou o saber e secundarizou aspectos relevantes das socialmente supostas ou qualificadas patologias (para uma análise sobre 
problemas metodológicos referentes ao estudo de "patologias sociais", ver: Becker 2 e Velho 3 ).

O movimento de temperança do século XIX, emergido principalmente na sociedade americana, imputou uma imagem profundamente negativa aos bebedores 4,5,6. O desenvolvimento de saberes referidos ao alcoolismo como doença (a partir de Huss 7) colaborou para enfatizar seus aspectos negativos e para mobilizar a construção de controles sociais 8,9,10,11,12,13,14. Por isso, o interesse da pesquisa sobre a ingestão de bebidas alcoólicas tem sido mais concentrado sobre a embriaguez do que o beber e o beber, mais como desvio individual do que comportamento social 15.

Por tais circunstâncias, é preciso ter cuidado para não se cair na contraposição entre antropologia da saúde/doença ou antropologia do beber 13. Ambas estão referidas aos estudos de princípios de organização social e de construção das regras que presidem práticas coletivas. As transgressões não podem ser entendidas se apartadas das prescrições exaltadas.

Neste artigo, proponho-me a apresentar questões metodológicas que referenciam mas também são decorrentes de análises já elaboradas com base em situações de pesquisa empírica (este texto compõe um conjunto de análises sobre maneiras de beber e alcoolismo, elaboradas com base em pesquisa empírica realizada em bares e grupos de Alcoólicos Anônimos, sediados em bairros populares do Município de São Gonçalo, Estado do Rio de Janeiro. O trabalho de campo ocorreu entre novembro de 1999 e junho de 2001). Alguns dos problemas considerados são inerentes à perspectiva antropológica, quando aplicada ao estudo do alcoolismo. Como os termos alcoólatra e alcoolismo são ao mesmo tempo signos de diagnóstico, de insulto e de injúria, a explicitação das estratégias de controle de etnocentrismos torna-se um a priori metodológico irrecusável.

\section{O beber como ato social: sobriedades e exaltações}

O beber é um ato social embebido no contexto de valores, atitudes, normas, modos de classificação do tempo e concepções de realidade, muito freqüentemente implícitos nos comportamentos referentes 16. A consagração dessa perspectiva enaltece a descrição etnográfica de múltiplos casos e situações demonstrativas da diversidade de modos sociais de ingestão de bebidas alcoólicas (sobre essa diversidade de maneiras de beber - freqüência, características das bebidas, quem bebe, o que bebe, quando e como bebe etc. -, ver: Barthes 17; Bateson 18; Bernand 11,19,20; Bihl-Willete 21; Bott 22; Bourdieu 23; Boustany 24; Caro \& Morin 12; Castelain 25,26,27; Desjeux et al. 28; Elias 29; Fabre-Vassas 30; Faugeron 31; Gurr 32; Hell 33; Houtaud 34; Jardim 35; Le Guirriec 36; Machado-da-Silva 37; Nourrison 38; Véquard 39). Por isso, torna-se mais adequada a referência a maneiras de beber, construções sociais orientadas por atitudes e crenças que definem proscrições e prescrições.

Cada sociedade tem colocados em relevo os padrões institucionalizados de uso das bebidas alcoólicas, a variedade de modos de produção, de motivos e de oportunidades construídas para o ato social de alcoolização. O catálogo dos motivos que referenciam as maneiras de beber não corresponde, necessariamente, ao resultado do comportamento, mas do aprendizado das atitudes culturalmente atribuídas aos diversos usos.

Para que as bebidas sejam acessíveis, é fundamental que se conheça o manual de produção, de uso e de ingestão. A transferência geracional destes saberes inclui o processo de aprendizagem sob dosagens repetidas, para permitir a confiante identificação dos efeitos reconhecidos pelo ampliado e ampliável catálogo de motivos. O processo de aprendizagem da transição mediada pela bebida inclui a superação de efeitos desagradáveis, como freqüentemente acontece com a primeira experiência com o tabaco, com o álcool etc. 2,3.

Cada sociedade tem estabelecidos os momentos de beber (os diferentes significados atribuídos aos variados contextos), ou seja, os modos designados de periodização do tempo. $\mathrm{O}$ comportamento relacionado ao momento de beber serve para organizar a experiência temporal, devendo então ser estudado na articulação com sistemas de estruturação social, orientações culturais e condições ecológicas 16,40.

A definição do contexto possível já é indicadora das formas de controle social. Beber em grupo acena para a proscrição de que não se deve beber sozinho ou ao desabrigo dos valores e afiliações comunitárias. Beber isolado, na maior parte dos casos, não se associa a um costume da sociedade, salvo em atividades periféricas de grupos relativamente insulados, ou sociedades referidas a ideologias individualizantes. A emergência da concepção de alcoolismo é expressiva da consolidação dessas ideologias, pois que caldatária do contexto de construção das sociedades urbanizadas, do deslocamento individualizado de pessoas e das alternativas de acesso à bebida sob improviso, no curso de uma jornada, no retorno para casa 41 . 
Mesmo que a ingestão de bebidas alcoólicas seja valorizada para alcançar ou alterar estados de consciência e de expressão de sentimentos, essa transição prescrita deve ocorrer em contextos especiais, geralmente associados à ingestão de alimentos e à facilitação de atividades interpessoais, portanto, administrada pela situação coletiva.

Por isso, é importante distinguir e contextualizar os significados dos termos culturais que demarcam as distinções: alcoolização, embriaguez, alcoolismo, bebedor, bêbado, embriagado, alcoólatra, alcoólico, alcoolista, alcoólico ativo, alcoólico passivo etc. Eles dizem respeito aos graus de tolerância e às atitudes de cada um destes diferentes estados. Em várias sociedades não é o álcool que é condenado, mas o comportamento desviante dos indivíduos. Em conseqüência, há uma recorrente valorização do homem que sabe beber sem se alcoolizar e sem interferir no desempenho de papéis a ele atribuídos.

Nas sociedades ou nos contextos em que a alcoolização faz parte de um código de polidez, o abstinente é socialmente constrangido. Ela aparece de forma institucionalizada nas relações que se objetivam nos espaços de celebração do rito social de constituição do bom bebedor, como é o caso dos bares. A alcoolização se associa, para alguns, impositivamente, ao reconhecimento da internalização da identidade masculina 35,37,42. Nessas situações, a obrigação do uso do álcool como código de polidez tem a função de "lubrificante social" 21,26,28,38.

Em decorrência desta função, alguns segmentos profissionais se crêem obrigados a consumos freqüentes ou mesmo a hiperconsumos, bem como a condicionamentos. O estranho que a eles deve se integrar, incorpora o consentimento e a imitação desses hábitos, assimilando-os como próprio 26,43,44.

No bar, templo consagrado à alcoolização controlada, a bebida estabelece entre os homens um jogo de trocas e vínculos sociais. Por isso, o anonimato e o isolamento são provocativos da desconfiança, da suspeita e da exclusão das redes de relações que se instituem entre fregueses e donos de bar 45. A desvalorização do homem que recorrentemente aí bebe sozinho, evidencia a rejeição ao desvio comportamental: o rompimento com as reciprocidades estabelecidas nos bares.

Em cada sociedade, o estabelecimento do contexto da ingestão de bebida também se objetiva na construção de uma hierarquia entre as bebidas ou na construção de um significado especial para cada uma delas. É o que bem expressa o uso de bebidas variadas durante ou depois das refeições; ou as desqualificações atribuídas a aguardentes, em suas mais diversas possibilidades.

Torna-se então evidente que as propriedades simbólicas atribuídas às bebidas produzem usos ritualísticos próprios. Seus atributos só podem ser entendidos pelo estudo dos sistemas de crenças criados em torno delas. Em conseqüência, o ato social de ingestão da bebida alcoólica não pode ser estudado sem que sejam levados em consideração os sistemas de crenças no controle do comportamento e da socialização.

\section{O alcoolismo como objeto de estudo antropológico}

As resistências e as reticências dos antropólogos em relação ao reconhecimento do alcoolismo como objeto de estudo se devem a várias posturas erigidas em dogmas epistemológicos. Uma delas é a referência obrigatória à relatividade cultural, posto que o uso do álcool como problema e seu coadjuvante, o alcoolismo, estão ausentes em várias sociedades, embora a embriaguez seja freqüente e, por vezes, altamente estimada (sobre a historicidade da noção de alcoolismo, ver: Ancel \& Gaussot 8; Bernand 11; Huss 7; Jellinick 14; Sournia 46; Suissa 47).

Esforçando-se, no início do século, para se distinguir dos preconceitos dos missionários e administradores, que tendiam a ampliar o problema, acautelando-se da imposição de uma visão inerente à sua própria sociedade, os antropólogos negligenciaram a questão do uso culturalmente inadequado de bebidas.

Segundo interpretações apresentadas por resenhadores 48,49 - sob o a priori de que trabalhos etnográficos sobre uso de bebidas são afetados por definições culturais -, as perspectivas dos antropólogos são diferentes conforme a consagração do conceito de alcoolismo. $\mathrm{Na}$ literatura etnográfica que antecede aos movimentos de interdição do uso de bebidas alcoólicas, especialmente nos Estados Unidos, a "extrema" insobriedade foi mais recorrentemente registrada. Por isso, os resenhadores acima referidos entram em acordo quanto à constituição desse campo temático (na Antropologia) por volta da década de 40. Mas a contribuição analítica dos antropólogos se amplia a partir da década de 50, em face, inclusive, da difusão do uso do álcool em "sociedades primitivas" sob colonização; ou pela relevância temática da associação entre a difusão do uso e o controle de bebidas pela conversão religiosa 9,10.

O estudo do alcoolismo entre os antropólogos foi então estimulado pela tomada de posi- 
ção política frente aos efeitos - cultural e socialmente - catastróficos da inclusão da ingestão do álcool entre os membros das sociedades não-ocidentais ou não-industriais. Entretanto, a partir da década de setenta, os antropólogos expandem seu campo de ação para o estudo das sociedades industriais. Incluem fontes e dados utilizados por especialistas da análise e da intervenção no uso e abuso do álcool. Integram equipes de serviços de clínicas médicas e centros acadêmicos sobre o tema. Incorporam como segmentos etnografáveis os trabalhadores e a chamada classe média, mais recentemente integrada massivamente a consumos conspícuos e distintivos mediados pela bebida alcoólica. Portanto, os antropólogos se engajam com outros profissionais especializados no estudo do uso do álcool enquanto patologia. Esta inclusão, contudo, mantém a definição epistemológica do superdimencionamento do problema ou da patologia como qualificações emergidas historicamente na cultura ocidental.

Incluindo-se no debate pela relativização da dimensão do problema, os antropólogos (especialmente americanos) provocaram mudanças na perspectiva analítica dos que adotam a definição do uso abusivo do álcool como patologia. Colocaram em causa a associação entre o alcoolismo e os efeitos anômicos, por meio da inversão da perspectiva: a anomia, se aceita enquanto categoria explicativa da dinâmica social, seria causa e não conseqüência. Mas deram pouca contribuição ao entendimento dos princípios éticos de constituição de uma patologia social, porque mantiveram uma perspectiva funcionalista. Destacaram o uso do álcool pelo seu efeito relaxador dos constrangimentos culturais e facilitador de aprendizados diversos, conforme cada cultura. Reivindicaram a exemplaridade das situações de ingestão de bebida alcoólica para o estudo das formas de pensamento e ação que orientam o comportamento social, inclusive o referido por processos mentais inconscientes 22 .

Room 49 , elaborando uma resenha de textos apresentados em alguns congressos, sistematizou os modos de constituição da antropologia americana voltada para o tema: em contraste com a epidemiologia. Esta contraposição, destaca, cada vez mais se acentua pela reprodução ampliada das sociedades integradas ao campo etnográfico, especialmente os segmentos sociais dos quais os antropólogos são originários.

Entre os antropólogos que se ocuparam do estudo das maneiras de beber e da relativização dos significados do termo alcoolismo, destaco ainda a contribuição de Mary Douglas, uma referência obrigatória. No texto em que apresenta os comentários introdutórios ao livro Constructive Drinking-Perspectives on Drink from Anthropology, Douglas 50 reconhece que os antropólogos têm valorizado as investigações sobre os modos de pensamento e ação referentes à bebida, desde que ressalvada a historicidade da constituição do alcoolismo como problema. Adverte que os antropólogos oferecem melhor contribuição sobre as maneiras de beber de outras sociedades - não-ocidentais, onde o ato de beber está geralmente associado à festa e à sociabilidade e a embriaguez é valorizada e procurada, mesmo que sob mecanismos de controle dos excessos. Nestas situações, os homens são apreciados pela capacidade de beber e pela possibilidade de gastar recursos neste consumo conspícuo.

A especificidade da produção do saber antropológico sobre o alcoolismo não é reivindicada apenas pelos antropólogos americanos. A mesma caracterização é apresentada por Fainzang 13, analisando o campo temático francês. Segundo essa autora, os antropólogos vêm insistentemente investindo na construção de uma perspectiva específica para estudar os modos de ingestão de bebida e de alcoolização. Reafirmam como objeto de estudo as maneiras de beber, a partir das práticas sociais que elas implicam, dos valores e da sociabilidade. Para tanto, contrapõem-se aos sociólogos e aos epidemiologistas, recusando-se a incorporar categorias médicas, salientando a relatividade e a historicidade da noção do alcoolismo como doença, e enquadrando este último ponto de vista em contextos específicos.

Entre os antropólogos brasileiros, o alcoolismo é tema tangencial ao estudo das relações sociais objetivadas por assíduos freqüentadores de bar. Machado-da-Silva 37 apresentou uma contribuição pioneira, ao eleger os significados atribuídos ao botequim enquanto um dos tipos de casas de bebida na sociedade urbana. Valorizando a análise dos temas de conversação, que aí se singularizam, ressalta que eles lançam luz sobre os modos de percepção e controle do alcoolismo, num espaço social consagrado ao uso de bebidas alcoólicas.

Relevando o papel do bar enquanto espaço privilegiado de produção e reprodução de convívios rotineiros entre os homens (trabalhadores), Guedes 42 oferece exemplos etnográficos sobre os modos de controle do consumo de bebidas alcoólicas. Segundo ela, o autocontrole é parte do comportamento masculino esperado, sendo o bêbado então desclassificado e neutralizado segundo etiquetas de evitação. Essas etiquetas são parte da aprendizagem da freqüência assídua ao bar. 
Sobre esta definição ética do comportamento do bêbado, Machado-da-Silva 37 também já chamara a atenção, apontando a especificidade dos significados conforme o grupo de pertencimento social daquele que é visto como desviante (em relação ao padrão de consumo valorizado).

Assim sendo, o que importa aos antropólogos é muito mais o alcoolismo como um traço da cultura e muito menos como patologia. Situados sob condições de risco da adesão ao etnocentrismo, os antropólogos se apegam à confissão de fé: deve-se restituir o ponto de vista do consumidor sobre o consumo do álcool e o sistema de valores subjacentes que as maneiras de consumo exprimem e reproduzem 30 .

Contudo, restituir o ponto de vista do consumidor não assegura o afastamento da equação alcoolismo = doença, quando este for o ponto de vista do pesquisado. Daí a importância que vem sendo atribuída aos estudos sobre os movimentos dos antigos bebedores ou à reflexão sobre o sentido da abstinência compreendida como valor, como terapia ou como princípio organizador da existência.

\section{O alcoolismo como fenômeno socialmente construído}

Ao se tomar o alcoolismo como objeto de estudo, é fundamental explicitar os modos de superação de preconceitos e de disposições mentais, inculcadas pelas formas de representação cultural que a ele atribuem significados. Estes $a$ priori têm sido em grande parte indutores da exclusão da reflexão temática, ou salvaguardas do risco da inclusão nos universos dos agentes da acusação. Mas é também fundamental valorizar empiricamente as situações de produção de ilegitimidade do consumo do álcool, destacando que as atitudes constituem fatos a serem explicados. Portanto, não podem ser tomadas como explicação. A questão a ser investigada se desloca então para a compreensão do modo como os membros de segmentos sociais e culturais específicos se relacionam com a embriaguez. E, se presente, com a noção ou conceito de alcoolismo, sem cair na sedução da explicação do porquê.

A desconstrução de associações redutoras e moralizadoras mostra-se assim exercício imprescindível. Uma delas, bastante recorrente, diz respeito à equação pobreza, precariedade e alcoolismo. Há uma referência consagrada à associação do uso do álcool às massas trabalhadoras, razão pela qual ou construção com base na qual são legitimadas as intervenções ou sua preconização. De um modo positivo, a associação tende a valorizar a relação entre precárias e adversas condições de trabalho e uso sistemático ou abusivo de álcool. De um modo negativo, a associação tende a consagrar a articulação entre uso abusivo de bebida alcoólica e imprevidência individual, incompatível com desempenhos de papéis de esposo, companheiro e pai.

Da mesma forma, é importante ressaltar a impropriedade de isolar o alcoolismo como fenômeno social. Ele deve estar situado no quadro mais amplo de uso de bebidas e outras drogas lícitas ou ilícitas ${ }^{3}$. Retribuindo-lhe o caráter social, não é possível se abster de compreender os modos moralizantes de representação do alcoolismo: seus efeitos sobre a construção das relações sociais e sua atribuição como fator dissolvente de unidades sociais fundamentais como a família, ou perturbador do exercício de papéis básicos como trabalhador-esposo. Relativizando tais modos de construção e cristalização de representações, estes fatores são então considerados como mediações inerentes ao fenômeno social.

Diante de tais formas pré-construídas de concepção do alcoolismo, revela-se extremamente eficaz a análise das representações estruturantes dos discursos edificantes das ações militantes subjacentes ao projeto político antialcoólico. Neste campo de produção de idéias e de valores referenciadores do comportamento socialmente aprovado, passeiam com tranqüilidade as causalidades lineares e os determinismos absolutos (para a análise das formas de absolutização do ponto de inflexão da prevista trajetória do alcoólatra, qualificado como fundo de poço, tempo-espaço da desumanização física e social decorrente do uso imoderado de bebida alcoólica, ver: Garcia 51). A unidade de análise deve então recair sobre grupos e indivíduos relacionais, destacando que o alcoolismo aparece inseparável dos alcoólatras, dos alcoólicos e dos agentes autorizados à etiquetagem.

Sendo o alcoolismo definido como doença, por um lado está em jogo o poder de quem diagnostica e reivindica a legitimidade do enquadramento social. Definido como produto de uma vontade lábil ou do desabono da pessoa moral, está em jogo, por outro lado, o poder de quem desmoraliza. Desta análise, tornase então possível encaminhar a demonstração das condições sociais de possibilidade de existência contextual do fenômeno de desqualificação dos abusos não aprovados.

Sendo a designação explicitadora da produção e dos modos de cumprimento de padrões 
de regras de comportamento, o estudo dos casos de exceção, no contexto em que têm vigência, oferece oportunidades de entendimento dos atos de beber socialmente aprovados e de suas respectivas formas de controle. Tomando os temas subjacentes à elaboração da trajetória construída por alcoólicos para fazer emergir a representação sobre os pontos de ruptura, torna-se possível compreender os processos de socialização do bom bebedor, ou as regras e as normas que definem como beber. Portanto, o uso aprovado do álcool e o alcoolismo constituem-se em temas pertencentes a uma mesma sociologia da sociabilidade e aos mesmos sistemas sócio-culturais.

A situação ideal de pesquisa para estudar o processo de alcoolização e os modos de convivência daquele considerado alcoólatra, tem sido definida como o bar. Entretanto, este não se apresenta como espaço mais adequado para o estudo dos usos abusivos da bebida alcoólica, a despeito de aí ser bem explicitada a construção da acusação aos alcoólatras e, por contraposição, a consagração do bom bebedor.

Como, nessa situação etnográfica, colocar em prática o prezado princípio metodológico da Antropologia: o entendimento pelo modo de vida, pela consideração das atitudes e das percepções dos pesquisados? Como pedir para falar sobre o alcoolismo, o desclassificado como alcoólatra? Não seria o discurso do alcoolismo um produto social dos que o condenam? Portanto, quem, a priori, aceitaria ser entrevistado? O alcoólatra? Quem é o alcoólatra? O que internalizou a acusação e dela se valeu para produzir ressocializações negadoras desta mesma experiência. Aquele bebedor que, da ritualização da desqualificação, produziu requalificações positivas. Aquele que, da vivência sob liminaridade, transformou-a em situação redentora. E, por um ritual de passagem, pensou-se, em outras situações sociais, emergido por processos de ressurreição, sustentados em outras formas de socialização e de construção da identidade.

A entrevista com os heteroacusados de alcoolismo ou com os socialmente reconhecidos bêbados coloca o antropólogo diante da negação do ofício. Ele mesmo rotularia aquele com base no qual deseja compreender o processo de construção da acusação e do descrédito.

Por isso é recomendável estudar os significados de tais representações quando elaboradas nos espaços sociais construídos pelos alcoólicos vinculados a terapias ou à instituição dos Alcoólicos Anônimos. Aí são dramatizados os modos de construção do alcoólico como identidade redentora, graças à entre-ajuda ou à so- lução coletiva. Enfatizando a fragilidade da imagem de si, a necessidade vital do semelhante, a alteridade salvadora e o ser abstinente, os alcoólicos, nestes contextos assim reconhecidos, falam de si. Aí investem na expressão de uma adesão irrecusável e durável a um espaço coletivo, constituído pelos que supostamente viveram experiências semelhantes. Assumindo a perspectiva desqualificadora, construída pela alteridade ou pela valorização do ponto de vista do outro, investem na ressocialização diante da impossibilidade de cura, mas de predomínio de uma vontade absoluta. Tornando-se estranhos a si mesmos e aos seus pares, reafirmando-se por uma constituição especial e problemática - doente -, os alcoólicos vão deslocar o discurso e reinventar uma nova experiência de integração social. Nestes espaços está em jogo a produção de uma adesão ativa e proselitista. Adesão ritualmente explicitada, fundamentada num sistema de valores e crenças sistematicamente reproduzido, cujo efeito é a demonstração pública da eficácia simbólica da interiorização das representações coletivas construídas no grupo 13,51.

Relativizando o discurso heteroconstruído sobre os alcoólatras, ao antropólogo cabe reconhecer a maneira possível de entrar em contato com indivíduos sob tal condição. E, desde o início da pesquisa, assumir os limites impostos a este tipo de ação etnográfica e a especificidade das conclusões a serem alcançadas. Afinal, o alcoólico é aquele que assim se vê ou adota o ponto de vista acusatório do outro. Por essa adoção, investe na construção de um novo ponto de referência para a vida. E só com base nela fala de sua autocondenada experiência de $a l$ coólatra, então redimensionada e redefinida.

As considerações aqui apresentadas visam a contribuir para a construção de campos de pesquisa ainda secundarizados nas ciências sociais, mas também criar um diálogo com pesquisadores de outras disciplinas que se voltam para o tema em questão. O saber interdisciplinar não se confunde com um ponto de encontro de caminhos diferenciados. Opera pelo diálogo respeitoso das especificidades e dos limites de cada disciplina. Como a ingestão de bebida alcoólica, mesmo a considerada abusiva, constitui um ato social, a qualificação do abuso nada mais é que a denúncia coletiva da transgressão das regras a ele inerentes. A possibilidade social da embriaguez induz à construção de regras restritivas, tanto pelo bebedor abusivo como pelos que o condenam. Essas regras são também internalizadas pelo alcoólatra, como demonstra sua presença fugidia no bar ou a sua solidão e o diálogo supostamente 
consigo mesmo. Portanto, o beber qualificado como excessivo não pode ser compreendido apenas pela perspectiva da doença e do desvio ou tão somente pelo ato individual. Os padrões do uso do álcool, suas funções e significados são consoantes ao contexto cultural em que o ato de beber ocorre, mesmo que outros fatores também devam ser considerados, porque produzem importantes resultados bioquímicos, fisiológicos e farmacológicos.

\section{Resumo}

O artigo apresenta reflexões orientadoras da construção do consumo de bebidas alcoólicas como objeto sociológico, inclusive das formas proscritas articuladas à definição de patologias ou ao desrespeito a regras morais. Mediante considerações sobre o investimento acumulado por processo de pesquisa em curso, a autora destaca os dilemas éticos e epistemológicos enfrentados por antropólogos que se dedicam ao tema.

Alcoolismo; Consumo de Bebidas Alcoólicas; Transtornos Relacionados ao Uso de Álcool; Sociologia

\section{Agradecimentos}

Agradeço os seguintes bolsistas de iniciação científica vinculados ao Conselho Nacional de Desenvolvimento Científico e Tecnológico (CNPq), que participaram do trabalho de campo: Angela Maria Garcia, Marcel Robalinho Senra Peçanha e Patrícia Ferreira e Silva.

\section{Referências}

1. Durkheim E. O suicidio. Estudo sociológico. Lisboa: Editorial Presença/Livraria Martins Fontes; 1973.

2. Becker H. Outsiders. Glencoe: The Free Press/ MacMillan; 1966.

3. Velho G. Nobres \& anjos: um estudo de tóxicos e hierarquia. Rio de Janeiro: Editora FGV; 1998.

4. Gushfield JR. Status conflict and the changing ideologies of the American temperance movement. In: Pittman DJ, Snyder CD, editors. Society, culture and drinking patterns. New York: John Wiley and Sons; 1962. p. 101-21.

5. Gushfield JR. Symbolic crusade: status politics and the american temperance movement. Urbana: University of Illinois Press; 1963.

6. Soares BM. Mulheres invisíveis. Violência conjugal e novas politicas de segurança. Rio de Janeiro: Civilização Brasileira; 1999.

7. Huss M. Analyse de l'alcoolisme chronique par le Docteur Magnus Huss. Annales Médico-Psychologiques 1853; 5:60-88.

8. Ancel P, Gaussot L. Alcool et alcoolisme. Pratiques et represéntations. Paris: L’Harmattan; 1998.

9. Bacon MK. Alcohol use in primitive societies. In: Kissin B, Begleiter H, editors. The biology of alcoholism: social aspects. New York: Plenum Press; 1976. p. 23-37.

10. Bacon MK. Alcohol use in tribal societies. In: Kissin B, Begleiter H, editors. Social aspects of alcoholism. New York: Plenum Press; 1976. p. 1-36.

11. Bernand C. 1985. De l'invrognerie à l'alcoolisme. Informations Sociales 1966; 8:24-9. 
12. Caro G, Morin E, editors. De l'alcoolisme au bien boire. Paris: L'Harmattan; 1990.

13. Fainzang S. Ethnologie des anciens alcooliques. La liberté ou la mort. Paris: Presses Universitaires de France; 1996.

14. Jellinek EM. The disease concept of alcoholism. New Haven: Hill House Press; 1960.

15. Neves DP. A produção de conhecimentos sobre o consumo de bebidas alcoólicas. Análise de levantamento bibliográfico. Niterói: Universidade Federal Fluminense; 2001.

16. Hazan H. Holding time still with cups of tea. In: Douglas M, editor. Constructive drinking perspective on drink from anthropology. Paris: Cambridge University Press; 1987. p. 73-90.

17. Barthes R. Mythologies. Paris: Seuil; 1957.

18. Bateson G. Vers une écologie de l'esprit. Paris: Seuil; 1977.

19. Bernand C. Environements, idolâtries et illusions: Ivresses andines. In: Caro G, Morin, E, editors. De l'alcoolisme au bien boire. Paris: L'Harmattan; 1990. p. 239-45.

20. Bernand C. Désirs d'ivresse. Alcool, rites et dérives. Paris: Autrement; 2000

21. Bihl-Willete L. Des tavernes aux bistrots. Une histoire des cafés. Lausanne: Éditions l'Age d'Homme; 1997.

22. Bott E. The Kava ceremonial as a dream structure. In: Douglas M, editor. Constructive drinking. Perspectives on drinking from anthropology. Cambridge: Cambridge University Press; 1987. p. 182204.

23. Bourdieu P. La distinction: critique sociale du jugement. Paris: Éditions du Minuit; 1979.

24. Boustany A. Drogues de paix, drogues de guerre. Paris: Hachette; 1998.

25. Castelain JP. L'alcool: manieres de boire, manières de vivre et rapport aux autres. Psychotropes 1988; 4:61-8.

26. Castelain JP. Manières de vivre, manieres de boire. Alcool et sociabilite sur le port. Paris: Éditions Imago; 1989.

27. Castelain JP. Alcoolisation, sociabilité et identité sociale en milieu portuaire. In: Caro G, Morin E, editors. De l'alcoolisme au bien boire. Paris: L'Harmattan; 1990. p. 173-6.

28. Desjeux O, Jarvin M, Taponier S, editors. Regards anthropologiques sur les bars de nuit. Espaces et sociabilites. Paris: L'Harmattan; 1999.

29. Elias N. La societe du coeur. Paris: Flammarion; 1985.

30. Fabre-Vassas C. La boisson des ethnologues. Terrain 1989; 13:5-14.

31. Faugeron C, Kokoreff M. Les pratiques sociales des drogues: éléments pour une mise en perspective des recherches en France. Sociétés Contemporaines 1999; 36:5-18.

32. Gurr LA. Maigret's Paris, conserved and distilled. In: Douglas M, editor. Constructive drinking perspective on drink from anthropology. Paris: Cambridge University Press; 1987. p. 220-36.

33. Hell $B$. Manières de vivre, manières de boire: l'homme et la bière en Alsace. In: Actes de la Rencontre: Cultures, Manières de Boire, Alcoolisme; 1984 Jan 18-21; Rennes, France. Rennes: Bretagne Alcool et Santé; 1984. p. 53-9.
34. Houtaud A, Taleghani M. Sciences sociales et alcool. Paris: L'Harmattan; 1995.

35. Jardim DF. De bar em bar: identidade masculina e auto-segregação entre homens de classes populares [Dissertação de Mestrado]. Porto Alegre: Universidade Federal do Rio Grande do Sul; 1991.

36. Le Guirriec P. Alcool, culture et personnalité. In: Caro G, Morin, E, editors. De l'alcoolisme au bien boire. Paris: L'Harmattan; 1990. p. 149-57.

37. Machado da Silva LA. O significado do botequim. In: Kowarick L, organizador. Cidade: usos \& abusos. São Paulo: Editora Brasiliense; 1978. p. 77114.

38. Nourrisson D. Le buveur du XIXe siècle. Paris: Albin Michel; 1990

39. Véquard Y. Vive le haschisch. Paris: L'Esprit Frappeur; 1999.

40. Gushfield JR. Passage to play: rituals of drinking time in American society. In: Douglas M, editor. Constructive drinking perspective on drink from anthropology. Paris: Cambridge University Press; 1987. p. 73-90.

41. Nahoum-Grappe V. Histoire et anthropologie du boire en France. In: Nahoum-Grappe V, Le VotIfrah C, Mathelin M, editors. De l'ivresse à l'alcoolisme. Etudes ethnopsychanalytiques. Paris: Dunod; 1989. p. 83-169.

42. Guedes SL. Jogo de corpo. Niterói: EdUFF; 1997.

43. Gaboriau P. Le clochard. Paris: Julliard; 1993.

44. Neves DP. La misère en spectacle. Cahiers du Brésil Contemporain 1994; 25/26:61-80.

45. Garcia AM. Os bares no contexto de um bairro popular [Relatório de pesquisa: O alcoolismo e a exclusão social]. Niterói: Universidade Federal Fluminense; 2000.

46. Sournia JC. Histoire de l'alcoolisme. Paris: Flammarion; 1986.

47. Suissa AJ. Pouquoi l'alcolisme n'est pas une maladie. Québec: Fides; 1998.

48. Heath DB. A decade of development in the anthropological study of alcohol use. In: Douglas M, editor. Constructive drinking perspective on drink from anthropology. Paris: Cambridge University Press; 1987. p. 73-90.

49. Room R. Alcohol and ethnography: a case of problem deflation? Curr Anthropol 1984; 25:16991.

50. Douglas $M$, editor. Constructive drinking perspective on drink from anthropology. Paris: Cambridge University Press; 1987.

51. Garcia AM. A noção do fundo do poço e a viabilidade dos Alcoólicos Anônimos [Relatório de pesquisa: O alcoolismo e a exclusão social]. Niterói: Universidade Federal Fluminense; 2001.

Recebido em 17/Out/2002

Versão final reapresentada em 7/Jul/2003

Aprovado em 22/ Dez/2003 
Debate sobre o artigo de Delma Pessanha Neves Debate on the paper by Delma Pessanha Neves
O artigo de Delma Pessanha Neves, Alcoolismo: Acusação ou Diagnóstico?, representa uma tentativa de refletir o problema como objeto sociológico, de forma articulada à definição de patologia ou ao desrespeito a regras morais. A autora apresenta a temática à luz dos dilemas éticos e epistemológicos enfrentados por antropólogos, bem como por meio dos seus resultados da investigação empírica sobre o assunto.

A minha resposta ao desafio proposto por Cadernos de Saúde Pública neste debate foi formulada dentro de um quadro teórico e metodológico, o qual sustenta meu trabalho teóricoprático na prevenção e tratamento do alcoolismo, preservando as características interdisciplinar, extra-hospitalar e interinstitucional no nosso cenário prático, o Programa de Atendimento ao Alcoolista (PAA) do Hospital Universitário Cassiano Antonio Moraes (HUCAM) da Universidade Federal do Espírito Santo (UFES), ao longo destes 18 anos de enfrentamento da questão 1,2,3,4 e desde sempre assumindo o caráter construtivo na minha reflexão.

Neste sentido, a presente análise crítica não visa a abranger os múltiplos aspectos envolvidos na temática e, alguns deles mencionados por Neves, mas principalmente corroborar com a necessidade de clarificar os conceitos empregados neste artigo uso problemático de bebidas alcoólicas ("abuso do álcool") e alcoolismo ("síndrome de dependência do álcool” - SDA) 5,6.

Os problemas relacionados ao consumo de álcool nem sempre foram os mesmos e nem sempre tiveram a mesma dimensão, pois a relação do homem com a bebida vem mudando, principalmente nos últimos séculos 7 .

Nunca houve um período de "temperança" absoluta, mas até o final do século XVII o consumo de álcool era visto como uma atividade social. As cidades e vilarejos eram aglomerações de pessoas bem menores; tinham uma estrutura e organização sociais mais simples e, por isso mesmo, menos problemas. Ainda não havia a indústria da bebida, geralmente de produção caseira. Apesar da pouca legislação existente, havia fatores sociais e econômicos suficientes para controlar o uso "inadequado" da bebida, a embriaguez em larga escala. A em- briaguez era vista como sendo não um problema da bebida, mas do indivíduo: um defeito moral, de caráter, o levava àquilo, e contra tais casos se levantavam os pregadores religiosos. Mas a bebida ainda era vista como "um néctar divino" pela maioria das pessoas 8 . Nas primeiras décadas do século $\mathrm{XX}$, o alcoolismo ganha o status de doença, fornecido pela classe médica e pela associação dos Alcoólicos Anônimos. Os problemas associados ao álcool que mereciam preocupação eram aqueles relacionados ao colapso moral do bebedor crônico. Esses problemas eram vistos como não decorrentes de uma fraqueza moral do bebedor nem do poder aditivo do álcool em si, mas de alguma "química" pouco compreendida que ocorria entre a substância e certos bebedores. O álcool é inócuo para a maioria das pessoas, mas uma minoria não pode usá-lo sem sucumbir ao alcoolismo - uma doença para a qual não se espera cura além da completa abstinência. O problema é que tal concepção permite apenas "tratar" daqueles que são dependentes do álcool, deixando-se de lado a vasta maioria que bebe e que também apresenta diversos problemas relacionados ao consumo de álcool 9 .

A partir da última década do século $\mathrm{XX}$, o consumo de álcool começa a ser visto como uma questão de saúde pública, devido a extensão dos danos que acarreta, constituindo uma séria ameaça à segurança pública (danos à família, violência e crime, e segurança no trânsito, por exemplo). Políticas do álcool passam então a ser vistas como algo que diz respeito a todos os cidadãos cuja segurança possa estar em risco 10 . Também a partir da última década, diversos estudos vêm demonstrando que é possível combater tais problemas por meio de políticas públicas adequadas 11 .

As políticas públicas em relação ao álcool geralmente partem de uma concepção equivocada, fruto da idéia de alcoolismo do século anterior, que não encontra fundamento epidemiológico: a de que efeitos adversos do consumo de álcool afetam apenas a pequena minoria da população que bebe de maneira particularmente pesada. Esta minoria é vista como uma população à parte, em relação àqueles que não bebem pesadamente. Também existe uma tendência de focalizar apenas os problemas crônicos causados pelo consumo de álcool, negligenciando suas conseqüências adversas agudas.

Na verdade, há um amplo espectro de problemas relacionados ao consumo de álcool que vão muito além do conceito médico restrito de alcoolismo. Problemas podem surgir a partir de um único episódio de ingestão alcoólica ou de 
uma repetida ingestão pesada. Tais problemas podem ser de natureza física, psicológica ou social 12

Finalmente, agradeço a Neves a oportunidade que proporcionou-me de repensar a temática considerada, bem como o estímulo que este seu artigo oferece a quem se interessa pela pesquisa do alcoolismo no âmbito das ciências sociais.

1. Macieira MS, Gomes MPZ, Garcia MLT. Equipe interdisciplinar. Informação Psiquiátrica 1992; 11:130-1.

2. Macieira MS, Gomes MPZ, Garcia MLT. Programa de atendimento ao alcoolista do HUCAM-UFES. J Bras Psiquiatr 1993; 42:97-109.

3. Macieira MS, Gomes MPZ, Garcia MLT, Nakamura-Palacios EM. Núcleo de estudos sobre o álcool e outras drogas - NEAD. Revista HUCAM 2002; 11:10-4.

4. Garcia MLT, Gomes MPZ, Macieira MS, Couzi CM, Gonçalves PL, Silvestre J. Programa de atendimento ao alcoolista: 15 anos de ensino, extensão e pesquisa. Revista HUCAM 2001; 9:12-5.

5. Organização Mundial da Saúde. Classificação de transtornos mentais e de comportamento - CID10. Descrições clínicas e diretrizes diagnósticas. Porto Alegre: Artes Médicas; 1993.

6. American Psychological Association. DSM IV Manual diagnóstico e estatístico de transtornos mentais. 4a Ed. Porto Alegre: Artes Médicas; 1995.

7. Ministério da Saúde. A política do Ministério da Saúde para atenção integral a usuários de álcool e outras drogas. Brasília: Ministério da Saúde; 2003.

8. Moore MH, Gerstein DR, editors. Alcohol and public policy: beyond the shadow of prohibition. Panel on alternative policies affecting the prevention of alcohol abuse and alcoholism. Washington DC: National Academy Press; 1981.

9. Laranjeira R, Romano M. Políticas públicas para o álcool. São Paulo: Universidade Federal de São Paulo; 2001.

10. Holder HD. Alcohol use and a safe environment. Addiction 1997; 92 Suppl 1:S117-20.

11. Casswell S. A decade of community action research. Subst Use Misuse 2000; 35:55-74.

12. World Health Organization. A summary of alcohol policy and the public good: a guide for action Eurocare - Advocacy for the prevention of alcohol related harm in Europe. Geneva: World Health Organization; 1995
Denise Fagundes Jardim

Programa de Pós graduação em Antropologia Social, Universidade Federal do Rio Grande do Sul, Porto Alegre, Brasil. dfjardim@portoweb.com.b
É uma grande satisfação poder participar deste debate e reencontrar-me com tuas propostas de análise sobre "usos do álcool". Eu agradeço o convite dos editores, que além de me conceder o privilégio de participar deste debate, me colocam novamente em contato com teu modo reflexivo e atuante de fazer antropologia.

Primeiramente, gostaria de situar de que ângulo este debate vem me instigando. Como sabes, e devo explicitar aos leitores, minha experiência com o tema "alcoolismo" está mais vinculada a uma preocupação e à necessidade de compreender fatos e contextos sociais que envolvem o uso de bebidas alcoólicas, do que um envolvimento direto em settings de pesquisa com aqueles que propõem ou se submetem a terapias.

É do ponto de vista de quem realiza trabalho de campo em antropologia que me permito algumas considerações sobre o artigo exposto, no sentido de provocar e te ouvir mais a respeito do tema. Em verdade, depois de observar outras experiências com os debates sobre o uso do álcool, partilho de tua preocupação em aproximar perspectivas analíticas que estão envolvidas com terapias disponíveis para o alcoolismo. Acredito que, assim como a prática dos terapeutas, o fazer etnográfico tenha de constantemente ser repensado perante novas exigências e, nesse ponto, gostaria de compartilhar algumas preocupações que me ocorrem ao ler teu artigo.

Referes a um "estado da arte" da compreensão dos antropólogos sobre os usos do álcool. Levantas questões que, a título de provocação ao debate, eu me permito carregar nas tintas, sublinhar e enfatizar. Minhas considerações referem-se a uma crítica possível aos trabalhos dos antropólogos, me incluindo como parte criticável e que teu artigo tangencia de maneira muito suave. Vou me ater a primeira parte do artigo, embora esse circuito da estigmatização me pareça muito instigante e gostaria de mais detalhes sobre essa moralização e como se entrelaça aos processos terapêuticos. A segunda parte de teu artigo trata da desqualificação daqueles que bebem e sofrem duplamente os custos da bebida e da estigmatização. Não vou me ater a essa segunda questão, da moralização e da estigmatização do doente, não menos importante, mas penso que a questão do sofrimento que emerge no circuito da bebida alcoólica é central para uma análise do alcoolismo.

É inevitável encontrar-me nessa síntese que inicia teu artigo, em que pese já passados pouco mais de dez anos de minha etnografia 
sobre masculinidade, em que o uso de bebidas era um dos acessos às falas masculinas em grupos populares. De fato, eu não aprecio muito as fórmulas terapêuticas absolutas e procedimentos únicos. Da mesma forma, prefiro as interpretações antropológicas mais circunscritas a contextos específicos do que aquelas que estendem interpretações válidas a determinados grupos e situações, absolutizando suas interpretações.

Preocupa-me a leitura que dispomos das etnografias. Mesmo que os antropólogos discorram sobre a necessidade de contextualizar os usos do álcool, parece que a leitura que temos feito das etnografias produzidas tem dado margem a uma absolutização de seus resultados e uma livre transposição de suas interpretações de um contexto ao outro. Contextualizadas, elas revelam tramas muito específicas e peculiares aos contextos observados.

Por intermédio de tua síntese, as etnografias parecem complacentes como os usos e abusos das bebidas e, por vezes, resguardados na literatura clássica, acabamos cegos perante o sofrimento (e o drama social) externalizado na ingestão de bebidas alcoólicas. Aqui parece que estou fazendo um mea culpa, mas a diferença entre meu setting de pesquisa e do circuito do alcoolismo explicitado no artigo, parece que é o da ocultação/explicitação dos discursos sobre o sofrimento por parte dos informantes. Em meu setting, seguia a retórica nativa. Eu diria, retrospectivamente, que o enfrentamento com o tema do uso do álcool quase sempre parece levar a perspectivas já consagradas na antropologia, mas há riscos nisso. Ao colocar em relevo o "ponto de vista do nativo", essa que seria a principal virtude da etnografia, por certo pode embaçar outras faces dessa questão, e não deixa devidamente explícito que algo culturalmente concebido também está sob o signo da negociação de significados, da violência simbólica, da pressão em eliminar ou conformar a atitudes discrepantes.

Salvaguardados pelo ofício, embuídos da necessidade de retratar "o ponto de vista do nativo", o lugar da observação e os atores envolvidos escapam das pressões de outras falas sobre os informantes, em seu mundo social, ou seja, o que é dito sobre eles por seus familiares ou amigos.

Todavia, lendo o artigo, antes de descartar os clássicos, penso que talvez tenhamos de repensar o modo como apresentamos as etnografias que referem aos usos do álcool, para antropólogos e para os leitores da antropologia. Ainda que estejamos compartilhando a premissa de que existam prescrições "culturais", controle social, será que falhamos na explicitação do sofrimento que envolve a dinâmica dos atos de beber?

De outro lado, compartilho com a idéia de que nesse tema, me parece que a interdisciplinariedade poderia usufruir das etnografias, de sua predileção por compreender contextos, de sua capacidade de compreender relações sociais em que está envolvido o sujeito que bebe, de seu mundo social, sem se levar pela urgência de interpretações transculturais (porque informadas em experiências diversas) e válidas a diferentes contextos.

Estas certezas tão cruciais e cotidianas para aqueles que estão envolvidos com práticas terapêuticas, poderiam resultar em uma descontextualização do sujeito concreto de suas relações sociais e de sua situação de "sofrimento". Voltamos a um questão muito difícil, a de manter um debate sobre a extensão e plasticidade do sofrimento, sem necessariamente simplificarmos a questão e exigirmos consensos sobre suas causas.

Enfim, o que seria uma perspectiva antropológica sobre o alcoolismo? Parece uma encruzilhada entre a antropologia que focaliza os usos de bebidas alcoólicas (quase sempre estudos comparativos que têm como fio condutor "estados alterados da consciência”) e uma antropologia da saúde/doença que, de um modo mais amplo, eu preferia chamar de uma antropologia sobre o sofrimento.

A dúvida parece beneficiar o trabalho do antropólogo, dada a ambigüidade e porosidade dessa encruzilhada. Estamos tratando do alcoolismo ou de maneiras de sofrer e de sofrimentos (mais amplos e mais difusos) que cruzam seus caminhos em uma mesma sala de espera, e que adquirem uma mesma classificação, e até uma redução de sua complexidade como alcoolismo.

De qualquer forma, os circuitos de bebidas se apresentam de modos muito diversos, desde sua produção e comercialização, até o modo como se tem acesso ao álcool e a quais bebidas (industrializadas ou destiladas em larga escala). Essa variedade tem transpassado as fronteiras entre sociedades tradicionais e industriais, a ponto de não podermos mais dizer que uma etnografia dos usos do álcool na "nossa sociedade" ou sobre a de "sociedades tradicionais" sejam previamente conhecidas.

Concordo que estamos mais familiarizados com os clássicos sobre os usos do álcool (em sociedades tradicionais), mas há uma produção recente que encara o circuito da alcoolização como algo mais vasto e perturbador do que suporta o controle social disponibilizado na "al- 
deia”, exigindo arranjos próprios e revitalizando tradições para estabelecer um controle social efetivo. E, portanto, mesmo evidenciando modos tradicionais de uso e ingestão das bebidas, ou uma leitura nativa do "alcoolismo" como um mal da sociedade do branco, a interpretação dos antropólogos sobre o que provoca e como se manifesta, está sempre impregnada da busca do ponto de vista dos nativos sobre o corpo e as origens da doença e, portanto, focalizando uma trama específica do sofrimento. Portanto, essa seria uma terceira perspectiva (nem a de análise em sociedades tradicionais, nem a encapsulada na "nossa" sociedade) que beneficiaria a perspectiva dos etnógrafos sobre os usos do álcool. Como entendi (e estou correta na minha compreensão?), qualquer que seja "a sociedade", deveríamos encarar de frente a questão do sofrimento e o drama social, sem glamourizar o controle social e a cultura.

Me preocupa que a cooperação interdisciplinar tenha que partir de consensos prévios e transculturais sobre a necessidade de resgatar indivíduos do sofrimento e que o sofrimento é igual à bebida, sem verificar um circuito mais amplo em que se encontram a bebida, os bebedores e seu mundo social.

Em segundo lugar, parece-me que a interdisciplinariedade do debate reúne agentes que norteiam seu trabalho sob as mesmas urgências. Como tens encarado as arestas deste debate, que não necessariamente contemplam as mesmas exigências,certezas e, por vezes, agregam posturas pouco convergentes?

Será que o ingresso neste campo de debates, circunscrito ao tema "alcoolismo", não acaba pressionando recortes metodológicos, a urgência de questões específicas (e instrumentais) e elegendo settings de pesquisa como aqueles que por pressuposto seriam encontradas as chaves de compreensão à questão (em detrimento de outros)? Essa precipitação tem conduzido a explicações individuais da doença, em detrimento de uma análise mais complexa do fenômeno? Como tens reagido a esse tipo de pressão, de interpretações transculturais sobre os usos do álcool e de um campo de debatedores aparentemente tão estruturado?
Margarita Antonia Villar Luis

Escola de Enfermagem de Ribeirão Preto, Universidade de São Paulo, Ribeirão Preto, Brasil. margarit@glete.eerp.usp.br
No artigo Alcoolismo: Acusação ou Diagnósti$c o$ ?, Neves discorre sobre o uso de bebidas alcoólicas registrando a indevida atenção que tem sido dada a esse fenômeno ao mesmo tempo em que evidência a limitação da perspectiva tradicional, explicativa da questão do beber problemático, que embora utilize o conhecimento de várias disciplinas (biologia, psicologia, sociologia), ao contrário de fazer surgir um conhecimento integrado a respeito, fornece uma visão fragmentada que tornou secundários aspectos importantes. Ressalta a ênfase na imagem negativa do bebedor e do desenvolvimento da concepção do alcoolismo enquanto doença, ideário esse consolidado no movimento de Temperança (século XIX), ocorrido com mais intensidade nos Estados Unidos, num momento de profundas transformações sociais. Nesse contexto, o álcool passou a ser o responsável pelos problemas sócio-econômicos do país e a abstinência do mesmo, a solução. Lideranças mobilizaram a população em movimentos de massa contra o álcool, num processo de radicalização que culminou com a aprovação da Lei Seca que permaneceu em vigor de 1919 a 19331.

Era de se esperar que o foco das investigações fosse a embriaguez enquanto doença, doença da vontade do indivíduo, e como bem coloca a autora do artigo, de certa forma, isso foi direcionando o interesse dos pesquisadores para a produção de conhecimento dando prioridade ao aspecto da patologia individual e descuidando do ato de beber em si, enquanto um comportamento socialmente construído, estimulado e controlado segundo padrões culturais das sociedades.

$\mathrm{O}$ artigo discute, dentro de uma perspectiva etnográfica, o beber, o espaço onde ele geralmente se dá e a embriaguez, partindo das visões dos próprios atores sociais nos locais por eles freqüentados: o bar e o grupo alcoólicos anônimos, instância essa que os acolhe e dá suporte quando outras, de alguma maneira, negam-lhes o ingresso.

Sem a intenção de esgotar a complexidade dos tópicos abordados pelo artigo, cabe refletir sobre a análise feita no texto a respeito do beber como um ato social, pois cada sociedade vai transmitindo às sucessivas gerações, num processo de aprendizado, o padrão do beber, as condições e o contexto no qual é aceito esse ato, portanto, o próprio meio estabelece as estratégias de controle definindo a forma, o como e o momento de beber, priorizando os espaços e situações do coletivo. Assim, há neces- 
sidade de adaptar o beber a algumas pautas sociais que são consideradas em maior ou menor grau por aqueles que bebem substâncias alcoólicas. Esse diferencial vai gerar os diversos significados dos termos utilizados para distinguir o usuário (bêbado, bebedor, alcoolista) e os estados em que se apresenta (alcoolização, embriaguez) revelando a maior ou menor tolerância do meio às atitudes presentes nas diferentes situações, decorrendo daí a condenação do comportamento desviante e a valorização daquele que demonstra "competência" no beber: não se alcooliza e consegue manter a produtividade. Da mesma forma, valoriza-se o que bebe em grupo, pois o consumo individualizado, conforme assinala o artigo, não é um hábito construído pela sociedade, ele surge e se acentua à medida em que o individualismo se instala como um valor no âmbito da sociedade urbana que dificulta o encontro humano e oferece uma variedade de alternativas de acesso rápido à bebida. É esse contexto que faz emergir a concepção de alcoolismo.

$\mathrm{O}$ artigo de Neves remete a uma análise do alcoolismo feita por Berne 2, fundamentada num modelo sistêmico social em que, baseando-se em jogos, partiu da premissa de que não existe o alcoolismo ou o alcoólico, mas um papel chamado "o alcoólico, num determinado jogo".

Esse autor não centrou a questão beber em excesso como uma anormalidade bioquímica ou fisiológica, mas por meio da análise de jogos, focalizou seu interesse nos tipos de transações sociais vinculadas ao beber excessivo. Numa experiência criou o jogo do "alcoólico", desenvolvido com cinco personagens (que podem concentrar-se no início ou fim em dois).

Nesse jogo, o protagonista é o "alcoólico", destacando-se, também, o "perseguidor" ilustrado pela figura da esposa, o "salvador" papel representado pelo profissional. O quarto ator é o "bobo" ou "ingênuo", referindo-se a personagens que o apóiam financeiramente (a mãe ou o dono do armazém que lhe dá crédito). Também pode estar presente no quarto papel, a figura do "incitador", o bom sujeito, que oferece bebida sem que lhe seja pedida. Nesse jogo há, ainda, um "profissional auxiliar", que é o dono do bar ou o balconista, que desempenha o quinto papel: a "conexão", fonte direta de provisão de álcool. A diferença entre este e os demais “jogadores” é que ele pode e sabe quando interromper o jogo, ou seja, no momento em que ele se nega a servir bebida ao alcoólico. Com isso cessa a fonte provedora, a menos que ele vá em busca de outra "conexão" mais tolerante.

Por meio desse estudo, Berne 2 procurou mostrar que a dinâmica do alcoolismo está me- nos relacionada a motivações e características do alcoólico do que às interações entre aqueles que ocupam as cinco posições interpessoais descritas no jogo. Para esse autor, o comportamento do alcoólico é possível de ser compreendido apenas quando é percebido como parte integrante de um sistema interpessoal.

Considerando o conteúdo do artigo em análise, percebe-se que esse sistema interpessoal desenvolve-se no espaço cultural dos indivíduos de uma dada sociedade.

A breve síntese das principais colocações da autora no artigo, juntadas a outros dois autores, compõem um contexto propício à reflexão.

Direcionando o olhar do interno para o externo, ou seja, da discussão teórica para o usuário de álcool, inevitavelmente surge a questão: considerando a existência de estudos evidenciando que o beber pressupõe um contexto sociocultural indo além da situação de embriaguez e do indivíduo que bebe em excesso, por que então o foco permanece sobre o indivíduo e o estado patológico? Alguns podem dizer: mas a família está sendo incluída nas propostas de tratamento. Está mesmo? E se tal acontece, de que forma?

$\mathrm{O}$ artigo é instigante no sentido de que faz pensar em que medida, quando se sugere ou ministra o cuidado a esse e a outros grupos da população, é considerada ou valorizada a visão do cliente a respeito do fenômeno vivenciado: sua percepção, explicações, as estratégias consideradas viáveis para o enfrentamento e os personagens que julgam ser de ajuda nesse propósito.

A relação profissional com o indivíduo que bebe pressupõe um encontro de saberes (o científico com o vivencial) e de culturas, que embora possuam aspectos comuns mantêm suas peculiaridades. Cabe ao profissional ter consciência disso nas intervenções, sejam elas de prevenção do uso abusivo, tratamento ou reinserção na comunidade.

Para concluir o comentário vai aqui a última indagação: dado que o modelo de atenção imperante privilegia a doença e a condição de dependente, e os resultados no enfrentamento das questões relativas ao álcool (adesão do cliente ao tratamento, prevenção da recaída, prevenção do abuso) têm sido pouco animadores, não caberia uma "pitada" de humildade e repensar a prática, centrando desta feita, o foco da investigação e do cuidado no beber como um ato social? Ouvir e olhar o cliente elevando-o à categoria de protagonista, considerar os atores sociais não convencionais (donos de bar, por exemplo) nas ações preventivas do abuso, no tratamento e reinserção social, pode trazer surpresas gratificantes. 
1. Carlini BC. Movimentos e discursos contra as drogas: o caso da sociedade norte-americana. Revista ABP-APAL 1995; 17:93-101.

2. Berne E. Juegos em que participamos. México DF: Diana; 1966.

\section{Eurípedes Costa do Nascimento}

Grupo de Pesquisa: Psicologia e Instituições, Universidade Estadual Paulista Julio Mesquita Filho, Assis, Brasil. ecnascimento@hotmail.com
Primeiramente, gostaria de congratular a autora Delma Pessanha Neves pelas reflexões elaboradas sobre uma temática tão ampla e complexa como o alcoolismo e acrescentar, também, que estudos dessa natureza tornam-se necessários em nossa época contemporânea. Após uma leitura reflexiva sobre este manuscrito e fundamentada em grande parte pela sociologia francesa, apresento as seguintes considerações:

- Uma questão que, ao meu ver, parece importante para compreendermos os aspectos sociais do alcoolismo contemporâneo está relacionado aos modos de ser do homem, compreendido aqui como modos de produção de uma individualidade narcisista ${ }^{1}$ que busca a todo instante o reconhecimento e status por meio da encenação de si mesmo no espaço social 2. Nesse sentido, a necessidade de ser reconhecido no plano macrossocial, onde as aparências de sucesso contam mais que seus atributos pessoais, atinge também as relações estabelecidas pelo sujeito no plano microssocial, principalmente nas relações vivenciadas nos bares.

Desta forma, ser um "bom" bebedor significa se inserir num grupo onde sua mise-en-scè$n e$ vale mais que suas qualidades, funcionando, assim, como um catalisador dos laços sociais. Essa busca por reconhecimento nas relações vivenciadas nos bares pode ser compreendida, em parte, por essa necessidade de admiração do outro, além de um jogo de trocas e vínculos sociais, em que podemos observar no discurso do "bom" bebedor a valorização de uma narrativa sempre voltada para realizações "grandiosas" ou simplesmente na célebre exaltação à figura feminina como alvo de possíveis conquistas.

Portanto, para compreendermos a questão social do alcoolismo na atualidade, precisamos levar em consideração os (d)efeitos dessa vanglorização preconizada pelo culto da performance 3 , em que o sujeito precisa conquistar espaço e brilhar, custe o que custar, no cenário social. As implicações desse modo de se apre- sentar no mundo pode determinar, ao meu ver, as possíveis relações que estes sujeitos estabelecem consigo e com o uso de bebidas alcoólicas na contemporaneidade.

- Uma outra questão que me parece importante apresentar e está relacionada com a primeira, diz respeito aos avanços científico-tecnológicos que promete para o indivíduo o ideal de felicidade 4 e uma satisfação que pode ser perfeita, pois vivemos numa sociedade onde a técnica nos promete que não haverá mais nada impossível para nossa satisfação. Conjugado com o fenômeno da globalização, da flexibilização e da competitividade no mercado de trabalho, essa modalidade de discurso, ao meu entender, parece provocar uma certa instabilidade na constituição da subjetividade de determinados indivíduos que se preocupam mais com a aparência narcísica de si pela busca incessante de conquista e reconhecimento, que um posicionamento ético, estético e político.

Entretanto, se o indivíduo assim constituído não conquistar sua visibilidade no cenário social, potencializada, talvez, por possíveis fracassos pessoais, a necessidade de apaziguar essas frustrações 5 pode ser a recorrência ao consumo de álcool que, nessas circunstâncias, "solucionaria”, mesmo que ilusória e temporariamente, esse sentimento de mal-estar vivenciado pelo sujeito tanto no plano micro como macrossocial. Nesse caso, não seria o alcoolismo contemporâneo o resultado de um sintoma social agravado pela cultura do narcisismo que prioriza a performance da imagem? Ou ainda: será que o avanço científico-tecnológico não produz um certo desamparo no sujeito e o impulsiona a buscar no uso do álcool as soluções aliviadoras para sua subjetividade?

Seja como for, para compreendermos a questão do alcoolismo na contemporaneidade torna-se necessário, também, investigarmos como se constitui o sujeito moderno não apenas epistemologicamente, mas sociologicamente, antropologicamente, numa perspectiva que possibilite a construção de conhecimentos que sejam capazes de ultrapassar conceitos pré-estabelecidos na cultura, pois, equacionar alcoolismo = doença é permitir que ele seja usado tanto pelo indivíduo como pela sociedade para atenuar ou obscurecer problemas subjacentes essenciais - pobreza, deficiência mental, criminalidade e similares 6 .

1. Lasch C. A cultura do narcisismo. Rio de Janeiro: Imago; 1983.

2. Debord G. La société du spectacle. Paris: Gallimard; 1992.

3. Ehrenberg A. Le culte de la performance. Paris: Calmann-Lèvy; 1991. 
4. Freud S. Malaise dans la civilisation. Paris: Presses Universitaires de France; 1971.

5. Ehrenberg A. L'individu incertain. Paris: CalmannLèvy; 1995.

6. Vaillant GE. A história natural do alcoolismo revisitada. Porto Alegre: Artes Médicas; 1999.

Elizabeth S. Palatnik

Núcleo de Estudos e Pesquisas em Atenção ao Uso de Drogas, Universidade do Estado do Rio de Janeiro, Rio de Janeiro, Brasil. bethpalat@bol.com.br
“As considerações aqui apresentadas visam (...) também criar um diálogo com pesquisadores de outras disciplinas que se voltam para o tema em questão. O saber interdisciplinar não se confunde com um ponto de encontro de caminhos diferenciados. Opera pelo diálogo respeitoso das especificidades e dos limites de cada disciplina". Cito aqui a Dra. Delma Pessanha Neves - autora do artigo Alcoolismo: Acusação ou Diagnósti$c o$ ? - na medida em que suas palavras traduzem a intenção de minha participação neste debate: fazer uma troca em forma de diálogo, entre saberes e experiências diferenciados, mantendo sempre as suas especificidades e limites. O seu artigo me suscitou alguns questionamentos construídos, justamente, com base em minha experiência profissional (realizando trabalho clínico de apoio a mães e outros familiares de dependentes de drogas) e do meu trabalho de pesquisa (que situa esse trabalho clínico na perspectiva de gênero) 1 .

$\mathrm{O}$ artigo apresenta estudos a respeito de como é visto o ato de beber enquanto um ato social, como o alcoolismo se constrói enquanto objeto da antropologia e enquanto um fenômeno não natural mas socialmente construído. O bar é evocado como "templo consagrado à alcoolização controlada", sendo um dos lugares onde se realiza a pesquisa empírica da autora. Os homens que freqüentam o bar são citados como sendo "os" usuários de álcool, seja o uso em excesso ou controlado, em grupo ou individualmente. Ao falar em homens, fica nítido que não se toma este termo como sinônimo de seres humanos e sim como representantes de gênero. É claro que o eixo central do artigo não se constitui pela questão de gênero (e isso já pode ser lido no próprio resumo do mesmo). Por isso, a princípio, pareceria não haver necessidade de apontar se vai ou não se falar deste ou daquele gênero. Porém, o fato de todos os exemplos de usos e abusos (e o modo como diferentes culturas os constituem e controlam), apontarem para homens usando ou abusando, deu ênfase - na minha leitura do texto - a uma falta: a falta de mulheres que bebem ou, talvez seja mais propício dizer, a um silêncio com relação às mulheres que bebem.

E, então, surgiram estes questionamentos: a diferença de gênero, na questão do abuso de álcool, não coloca dificuldades metodológicas ou dilemas éticos e epistemológicos para o pesquisador? A sociedade não trata ou considera de modo diferente o homem alcoólatra e a mulher alcoólatra? Não falar sobre mulheres que bebem em excesso (ou seja, não dar exemplos que as contemplem) e não explicitar que se fará um recorte pelo qual somente homens alcoólatras serão pesquisados, nos permite deduzir que as mulheres não usam álcool na nossa cultura? Isso nos autoriza a pensar que não há mulheres alcoólatras ou que elas não se reconhecem enquanto tais? Ou o silêncio explícito com relação ao uso/abuso de álcool por mulheres estaria refletindo o silêncio ao qual as mulheres se encontram relegadas na nossa cultura, se considerado este tema baseando-se na ótica da dominação masculina 2 ?

A escolha do bar, como lugar de desenvolvimento de pesquisa empírica, poderia estar operando um recorte "silencioso" de gênero, na medida em que é um espaço basicamente freqüentado por homens. Há que se considerar, também, que no campo da dependência de substâncias (embora não exclusivamente nele) é notória a procura de ajuda por parte de mulheres quando essa ajuda é para "curar" ou "resolver" problemas dos filhos ou maridos: muitas vezes, é difícil o pedido de ajuda ser explicitado quando se trata de um tratamento para elas próprias (não somente quando elas são usuárias de substâncias, mas também quando são familiares de alguém que faz uso: não há um reconhecimento de necessidade de ajuda para si e sim de uma orientação para ajudar os outros) 1. Isto também remete à construção do papel da mulher na cultura ocidental enquanto "cuidadora" e responsável pela saúde, educação e comportamento dos filhos (e com os “outros", em geral) 3 .

Ao se silenciar com relação ao alcoolismo feminino, corre-se o risco de repetir uma certa "naturalização" operada pelo uso do termo "dependência química” que (além de negar a complexidade própria da questão das drogas, sejam elas lícitas ou ilícitas, por dar ênfase ao produto como causador da dependência, negligenciando concepções contemporâneas que apontam para a sua complexidade), reproduz um olhar não apenas do senso comum que considera os dependentes ou alcoólatras como sendo "todos iguais". 
1. Palatnik ES. Aborto e toxicomania: a descoberta e construção de um problema [Dissertação de Mestrado]. Rio de Janeiro: Instituto de Medicina Social, Universidade do Estado do Rio de Janeiro; 2002.

2. Bourdieu P. A dominação masculina. Rio de Janeiro: Bertrand Brasil; 1999.

3. Badinter E. Um amor conquistado: o mito do amor materno. Rio de Janeiro: Nova Fronteira; 1985.

\section{Cecília Loreto Mariz}

Departamento de Ciências Sociais, Universidade do Estado do Rio de Janeiro, Rio de Janeiro, Brasil. cemariz@alternex.com.br
O artigo Alcoolismo: Acusação ou Diagnóstico?, de Delma Pessanha Neves vem preencher uma lacuna não apenas na antropologia brasileira, mas em nossas ciências sociais em geral. Neves tem toda razão quando observa que em nossa antropologia, e eu diria o mesmo para a sociologia, o alcoolismo tem sido analisado apenas de forma tangencial. Há de fato uma carência de reflexões sobre o tema. Mas não é somente por suprir essa carência que esse artigo é muito bem vindo. É bem vindo também pela ampla revisão da literatura que apresenta, e ainda por apontar as contribuições dos antropólogos aos estudos sobre o tema, refletindo sobre as dificuldades desses estudos e as possíveis formas de superar tais dificuldades por intermédio do modo pelo qual se constrói o "consumo de bebidas alcoólicas” como objeto sócio-antropológico.

Um argumento central desse artigo é que, nas ciências sociais, o alcoolismo em si não pode ser o objeto de pesquisa, mas o hábito de beber em geral - "prescrito e proscrito". Não se pode entender o alcoolismo enquanto problema social sem entender o hábito de beber socialmente aceito, e tampouco sem compreender toda a cultura em torno do consumo de etílicos. Muito apropriadamente, Neves destaca que " as transgressões não podem ser entendidas se apartadas das prescrições exaltadas" (p. 8), salientando que a necessidade de analisar o hábito de beber é legítimo e aceito em cada sociedade.

No início do texto, Neves (p. 8) comenta que "o interesse da pesquisa sobre a ingestão de bebidas alcoólicas tem sido mais concentrado sobre a embriaguez do que o beber o o beber, mais como desvio individual do que comportamento social", mas não deixa claro a que pesquisa está se referindo aí. Com certeza não é a antropológica, pois em todo o resto do seu texto mostra como no caso da antropologia isso não ocorre. Pelo contrário, na antropologia, como também afirmaram outros pesquisadores citados no texto (como por exemplo, Mary Douglas), negligenciou-se o estudo do consumo socialmente inadequado de álcool.

Essa negligência, Neves explica, foi fruto de uma preocupação em se evitar o etnocentrismo. Argumenta que sendo a luta antiálcool muito forte entre grupos religiosos e missionários, a antropologia evitava se contagiar com esse tipo de discursos ideológicos. Por outro lado, a autora também aponta que embora fosse freqüente a embriaguez, o alcoolismo, como um consumo socialmente inadequado de álcool, não existia nas chamadas "sociedades simples" estudadas pelos antropólogos. Os antropólogos estudavam assim, como a ingestão do álcool era organizada e tida como legítima nos diferentes contextos sociais - e essa tem sido uma grande contribuição. Mas a crescente proporção de membros das chamadas "sociedades simples" que se tornaram bebedores problemas, desviando de seus padrões de consumo tradicionalmente aceitos, quando entravam em contato com a sociedade industrial moderna, leva a antropologia ao estudo do alcoolismo em geral.

No entanto, um problema se coloca para antropologia: como pesquisar o alcoolismo entre sujeitos que não se percebem nem se definem como alcoólatras? Ao chamar essas pessoas de alcoólatras ou alcoólicas, a antropologia estaria as "acusando" ou as "diagnosticando", abandonando assim a perspectiva especificamente antropológica? Neves (p. 12) argumenta " a entrevista com os heteroacusados de alcoolismo ou com os socialmente reconhecidos bêbados coloca o antropólogo diante da negação do ofício. Ele mesmo rotularia aquele com base no qual deseja compreender o processo de construção da acusação e do descrédito". A solução que autora aponta para o problema acima é que se considerem alcoólatras ou alcoólicos apenas os que se definem como tal, ou seja, aqueles que se encontram em terapias ou em movimentos do tipo dos Alcoólicos Anônimos. Por esse motivo, o bar não seria o melhor lugar para estudar o alcoolismo.

Pergunto se não estaria esse tipo de preocupação, em não definir quem é alcoólatra e estudar apenas a situação de tratamento, deixando de lado o problema mais amplo dos que convivem com o bebedor desviante e sofrem junto com ele as conseqüências sociais de seu desvio - ou seja, os familiares e amigos do desviante? Por que a antropologia não poderia adotar categorias sociais nativas entre aqueles para identificar os desviantes, mesmo que essas categorias fossem rejeitadas pelos desvian- 
tes? Em geral as categorias de acusação são rejeitadas pelos acusados.

Acredito que faz parte do estudo do alcoolismo e consumo da bebida analisar também os grupos sociais que fazem parte do universo do consumidor de álcool. $\mathrm{O}$ estudo sobre o alcoolismo não se refere apenas à identidade do alcoólatra, mas a todo o contexto social que o envolve, seja o bar, o trabalho, a família. Não estaria essa preocupação com a identidade do alcoólatra esquecendo dos problemas de interação social? Não seria uma abordagem reducionista? Se há acusações socialmente elaboradas pelos que estão em volta do sujeito, que desobedece as regras socialmente definidas de beber, por que elas não podem ser estudadas como categorias sociais pela antropologia? Acredito que se pode estudar os que usam essas categorias, como eles a constróem, quando as adotam. Enfim, por que a categoria alcoólatra teria de ser assumida pelo sujeito para ser estudada pela antropologia?

Como fica claro pelos comentários e questões acima, o texto de Neves é muito rico, instigante, traz questões e faz pensar.

Maria Odete Simão

Departamento de Neurologia e Psiquiatria, Faculdade de Medicina de Botucatu Universidade Estadual Paulista, Botucatu, Brasi modete@fmb.unesp.br
No artigo Alcoolismo: Acusação ou Diagnósti$c o$ ?, Neves discute os aspectos antropológicos envolvidos no uso de bebidas alcoólicas. Abordar o uso de bebidas alcoólicas em todas as suas formas (beber recreativo, abusivo, nocivo e dependência) não tem sido uma tarefa fácil e tão pouco possível de um único olhar (social, cultural, biológico). É sabido que existem vários fatores que influenciam o modo do indivíduo beber e o modo como a sociedade o vê, incentivando e/ou reprimindo sua ação.

Neves apresenta uma discussão sob o ponto de vista dos antropólogos, sem, no entanto, deter-se no aspecto da doença alcoolismo. Cabe lembrar que geralmente o início do uso de bebidas se dá sem grandes problemas, e em alguns casos, com o passar do tempo, uma ingestão que começou como "recreativa" passa a trazer problemas, e pode tornar-se a doença alcoolismo.

O uso de bebidas alcoólicas é comum e incentivado na maioria das sociedades atuais por ser considerado um desinibidor, um facilitador de relações, uma forma de diminuir as crescentes tensões do cotidiano. Assim, eventos come- morativos ou ocasiões festivas, entre tantas outras, tornam-se grandes aliados no início do uso de álcool.

Discutir o uso de bebidas alcoólicas não é necessariamente discutir a doença alcoolismo (Dependência de Álcool ou Transtorno de Comportamento decorrente do Uso de Álcool). É necessário avaliar, analisar cada comportamento e suas repercussões na vida global do indivíduo e do grupo social que o cerca (micro grupo - família e macro grupo).

O termo "alcoolismo crônico" foi empregado pela primeira vez em 1849 por Magnus Huss, para descrever um conjunto de manifestações patológicas do sistema nervoso, tanto psíquicas como motoras e sensoriais e que se instalavam, de forma progressiva, em pessoas que consumiam quantidades excessivas de bebidas alcoólicas durante muitos anos. Com o passar do tempo, esta denominação "alcoolismo crônico" tornou-se popular, designando tanto um importante fenômeno médico-social, como também de certa forma, estigmatizando seus portadores 1 . Além disso, sabe-se hoje que o alcoolismo é uma doença crônica sendo, portanto, redundante o uso desta terminologia.

Paralelamente às mudanças nosográficas ocorreram mudanças conceituais, nas quais a dimensão dos problemas relacionados ao uso nocivo do álcool deixou o plano meramente organicista e passaram a ser abordados, também, como parte de um fenômeno que se manifesta em variadas dimensões, expressando-se ao longo de distintos eixos: físico, psicológico e social 1 .

Para Genevieu Knupfer apud Bertolote 1, a gama de problemas associados ao alcoolismo implicaria problemas familiares, legais, no trabalho, de saúde e econômicos.

Voltando à questão do uso de bebidas alcoólicas, Dwight Heath (apud Madrigal 2), um reconhecido antropólogo e pensador americano, comentou sobre a ação de atitudes culturais tolerantes, que fazem do "beber" ou consumir drogas uma conduta ligada ao sexo masculino. Considera, de forma pertinente, que as normas, valores, atitudes e expectativas podem ser tão ou mais importantes que as diferenças biológicas entre os sexos, para definir o padrão de consumo e suas conseqüências.

$\mathrm{Na}$ abordagem deste assunto, é obrigatório considerar o nível educacional, social, cultural, a procedência rural ou urbana, além de outros fatores que poderiam influir na forma de as pessoas lidarem com problemas de ordem médica e que implicam também os valores sociais e morais, como é o caso do consumo de álcool e outras drogas. 
A literatura enfatiza além dos aspectos clínicos, os aspectos psicossociais envolvidos na doença do alcoolismo. Wilsnack \& Wilsnack 3 destacam o fato persistente de que em todas as culturas os homens bebem em maior quantidade e mais freqüentemente que as mulheres. Esse seria um padrão universal e recorrente em diferentes sociedades e culturas, inclusive na África, Ásia, Pacífico, América Latina, Europa e América do Norte. Mesmo com as mudanças sociais e oportunidades educacionais e de trabalho, incluindo as populações de adultos jovens de universidades, essa diferença permanece.

As tendências atuais no consumo de álcool consideram sua ingestão para "alegrar-se" ou o embriagar-se para "ficar bem", como uma conduta amplamente tolerável no homem. Na mulher, essa mesma conduta aparece como socialmente censurável, dependendo de sua origem sócio-econômica e cultural e da faixa etária. No entanto, nos Estados Unidos, a tendência generalizada, a não ser entre os estudantes universitários, é de se beber menos em todos os níveis sócio-econômicos, particularmente destilados. Às informações amplamente disponíveis e a maior conscientização dos perigos da ingestão excessiva são uma possível explicação para esse fato 4 .

Alguns autores consideram que o fato de o início da ingestão de álcool ocorrer na adolescência está associado geralmente a questões familiares (condições ambientais e perspectivas sociais ruins), à facilidade de aquisição, ao aumento da oferta, ao incentivo de amigos e ao reforço da mídia 5,6,7,8.

Diante disso, o artigo da autora tem grande importância quando nos faz repensar na amplitude dos termos, suas origens e a implicação cultural em que está envolvido.

1. Bertolote JM. Conceitos em alcoolismo. In: Ramos SP, Bertolote JM, organizadores. Alcoolismo hoje. Porto Alegre: Artes Médicas; 1997. p. 17-31.

2. Madrigal E. Patrones de consumo y dependencia del alcohol y de substancias psicoactivas en la mujer. In: Gómez-Gómez E, editor. Género, mujer y salud en las Américas. Washington DC: Organización Panamericana de la Salud; 1993. p. 163-77.

3. Wilsnack R, Wilsnack SC. Gender and alcohol individual and social perspectives. New Jersey: Rutgers Center of Alcohol Studies; 1997.

4. Johnston LD, O'Malley PM, Bachman JG. National survey results on drug use from the monitoring the future study, 1975-1995: volume II. Washington DC: National Institute on Drug Abuse; 1997.

5. Haver B. Female alcoholics I. Psycho-social outcome six years after treatment. Acta Psychiatr Scand 1986; 74:102-11.

6. Henriques Jr SG. Alcoolismo: exclusividade mas-

culina? Jornal Paulistano de Psicossomática 1995; $1: 21-2$.

7. Pinsky I, Silva MTA. As bebidas alcoólicas e os meios de comunicação: revisão da literatura. Revista APB-APAL 1995; 17:115-21.

8. Oliveira LAC. Aspectos do alcoolismo feminino. Vivência 1998; 54:36-7.

\section{Cláudio Luiz Lottenberg, Anita Taub \& Sergio Nicastri \\ Hospital Israelita Albert Einstein, São Paulo, Brasil.}

\section{O alcoolismo e seus significados}

O artigo Alcoolismo: Acusação ou Diagnóstico?, de Delma Pessanha Neves traz à tona uma discussão fundamental. Ao abordar o consumo de álcool e o uso problemático dessa substância do ponto de vista social, a autora explora uma série de regras e códigos que regulam sua utilização pelos indivíduos, bem como o significado e até mesmo a aceitação dos comportamentos relacionados à utilização de bebidas alcoólicas. Interessante observar o quanto o conjunto de regras não escritas pode ter força maior do que muitas regras formalizadas em termos legais. Tomemos, por exemplo, a legislação que determina a proibição formal da venda de bebidas alcoólicas a menores de idade e a realidade em nosso país, onde observamos que essa barreira legal não é efetiva.

Embora seja fácil constatar que o consumo de bebidas alcoólicas não é necessariamente um problema de saúde, também é inegável que parte dos usuários dessa substância apresentam problemas recorrentes relacionados ao seu uso. Diferentes compreensões dessa situação estiveram na base de diversas respostas da sociedade em relação aos problemas relacionados ao consumo de álcool. Uma visão moralista, que considera o consumo excessivo de álcool como uma falha de caráter, esteve na raiz de movimentos proibicionistas que conseguiram obter a aprovação de legislação que tornou a substância ilegal nos Estados Unidos (a chamada “Lei Seca”), o que trouxe resultados discutíveis. Para o profissional de saúde, a visão alternativa do uso problemático de álcool como uma doença abre a perspectiva de tratamento. É evidente, entretanto, que essa possibilidade não exclui automaticamente a carga de significados pejorativos associados ao diagnóstico dessa condição, preconceitos esses que existem na população geral e mesmo entre os profissionais de saúde 1 .

O termo "alcoolismo" tem uma história relativamente longa, mas seu sentido é bastante 
variável. Até a década de 1940, ele era empregado para designar sobretudo as conseqüências físicas do consumo intenso e prolongado de álcool. Um outro conceito era o de "alcoolismo" enquanto uma doença em que se destaca a perda de controle sobre o comportamento de beber, causada por uma anormalidade biológica pré-existente, com uma evolução progressiva previsível. Na década de 1950, Jellinek e outros estudiosos começaram a utilizar o termo para denominar o consumo de álcool levando a qualquer tipo de prejuízo: físico, psicológico ou social. Devido à imprecisão do termo, a Organização Mundial da Saúde tem evitado sua utilização desde o final da década de 1970, preferindo a formulação mais exata de síndrome de dependência do álcool, como um caso específico dentre uma ampla gama de problemas relacionados ao álcool. Apesar disso, "alcoolismo" ainda é um termo bastante empregado popularmente e mesmo entre profissionais de saúde. Na década de 1990, a American Society for Addiction Medicine definiu "alcoolismo" como uma doença crônica primária, com fatores genéticos, psicossociais e ambientais influenciando seu desenvolvimento e manifestações, freqüentemente progressiva e fatal, caracterizada por um descontrole contínuo ou episódico do comportamento de beber 2. A Classificação Internacional das Doenças não inclui o termo em sua 10a Revisão 3 .

A relação entre consumo de bebidas alcoólicas e saúde é complexa. Há muitas evidências de que quanto maior o consumo médio de álcool em uma população, maiores serão as taxas de ocorrência de problemas relacionados ao álcool (incluindo infrações de trânsito ao dirigir alcoolizado, mortalidade devida à cirrose hepática e crimes violentos). Essa associação também existe em nível individual, em que se observa que os riscos de desenvolver cirrose hepática, sintomas de abstinência e, no caso de mulheres, câncer de mama é proporcional ao consumo habitual de álcool do indivíduo 4 . Por outro lado, existem também evidências de que o uso de álcool em quantidades moderadas está associado à redução de riscos de infarto agudo do miocárdio, aterosclerose, acidentes vasculares cerebrais e osteoporose (em mulheres menopausadas), embora haja discussão sobre quais seriam os níveis de ingestão alcoólica que poderiam ser denominados como "moderados" 5. Enfim, mesmo do ponto de vista da saúde, não é fácil a tarefa de delimitar o consumo de álcool numa categoria de "doença”, embora essa possibilidade seja evidente em diversos casos.

Trabalhos como o de Delma Pessanha Neves são importantes para se entender melhor o

fenômeno do consumo de álcool, sobretudo os aspectos culturais envolvidos nesse comportamento, que certamente extrapolam as competências de áreas de atuação ou de conhecimentos científicos específicos. Uma melhor compreensão do consumo de álcool e seus diversos contextos é tarefa que certamente exige contribuições de várias disciplinas.

1. O'Brien CP, McLellan AT. Myths about the treatment of addiction. Lancet 1996; 347:237-40.

2. World Health Organization. Lexicon of alcohol and drug terms. Geneva: World Health Organization; 1994.

3. Organização Mundial da Saúde. Classificação de transtornos mentais e de comportamento da CID10: descrições clínicas e diretrizes diagnósticas. Porto Alegre: Artes Médicas Sul; 1993.

4. Edwards G, Marshall EJ, Cook CCH. As causas dos problemas com bebida. In: Edwards G, Marshall EJ, Cook CCH, organizadores. O tratamento do alcoolismo: um guia para profissionais de saúde. Porto Alegre: Artes Médicas Sul; 1999. p. 21-30.

5. Dufour MC. Defining "drinks" and drinking levels. Alcohol Res Health 1999; 23:5-14.

Florence KerrCorrêa

Departamento de Neurologia e Psiquiatria, Faculdade de Medicina de Botucatu, Universidade Estadual de São Paulo Julio Mesquita Filho. Botucatu, Brasil. fcorrea@fmb.unesp.br
Como qualquer outro comportamento humano, o uso de álcool, incluindo o alcoolismo, pode ser visto de vários pontos de vista: médico, antropológico, religioso, moral ou sociológico, entre outros. O termo alcoólatra foi abandonado pela maioria dos médicos, pois a doença correspondente teria de ser alcoolatria, adoração do álcool. A Associação Brasileira de Estudos do Álcool e de Outras Drogas recomenda o termo alcoolismo para a doença e alcoolista para o dependente.

Conforme destaca a autora, foi no século XIX, com os trabalhos de Huss, que os quadros associados ao abuso do álcool foram descritos e sistematizados. Não que não se soubesse dos malefícios que o álcool pudesse causar, mas por causa do preço, seu uso era restrito a ocasiões festivas ou às camadas da população com alto poder aquisitivo. Além disso, a qualidade das bebidas, de um modo geral, era tão ruim, que Grimod de la Reynière 1, em seu manual dos anfitriões, fala da praxe da diluição do vinho com água, ao gosto de cada convidado, pois o vinho de boa qualidade, passível de ser tomado "puro", seria muito caro para recepções. A democratização do acesso às bebidas deu-se com a industrialização, que melhorou a 
sua qualidade, tornou-as mais baratas e possibilitou a produção, particularmente de destilados, em grande escala.

No artigo, Neves, apesar de falar do uso de álcool, não discorre sobre alguns dos achados epidemiológicos mais interessantes na área e que mereceriam uma abordagem antropológica mais consistente, pois mostram a diferença de representação que o uso de bebidas alcoólicas tem para os gêneros 2. Assim, como bem demonstra a metanálise de Fillmore et al. 3 , em todas as culturas ocidentais onde o álcool é a droga legal (para maiores de 18 anos) mais utilizada pela maioria, inclusive no Brasil 4,5, homens bebem mais que mulheres, e jovens mais que idosos. Wilsnack \& Wilsnack 6,7 destacam esse padrão universal e recorrente em diferentes sociedades e culturas, considerando quantidade e freqüência, chamando a atenção para o fato de que, apesar das mudanças sociais e oportunidades educacionais e de trabalho, essa diferença entre os sexos permanece.

$\mathrm{Na}$ área da saúde, nos últimos 15 anos, o diagnóstico deixou de ser feito apenas naqueles casos em que, comprovadamente, se pode falar de uma doença cerebral (dependência do álcool) - casos estes nos quais há um conjunto de alterações cognitivas, comportamentais e fisiológicas comprovadas 8 . Ampliaram-se as possibilidades de diagnóstico dos anos 80 para cá, com o advento da classificação americana de doenças mentais, o DSM-III 9. Passou-se a fazer o diagnóstico de uso abusivo (ou nocivo), levando-se em conta os problemas que ocorrem na esfera familiar, jurídica, social, ou mesmo clínica, porém sem a dependência com sua tríade necessária de tolerância, dependência (física e psíquica) e abstinência. Esses casos são pelo menos cinco vezes mais freqüentes que os de dependência 5,10. A isso se junta certo padrão de uso de bebidas alcoólicas chamado de "beber tomando porre" (o binge drinking da literatura inglesa), responsável por mais mortes que a dependência do álcool, seja por dirigir embriagado, seja por comportamentos de risco, levando à violência, homicídios e traumatismos, constituindo-se, ainda, na principal causa de morte entre jovens, no Brasil. Tem-se aqui, o paradoxo da prevenção: casos mais leves e que nem são de doença tornam-se os responsáveis pela maioria dos problemas 10,11.

Para quem trabalha na área de prevenção, os problemas são ainda maiores, e preconceitos intervêm claramente. Se, em muitos países, principalmente mediterrâneos (wetcultures), o álcool é visto como alimento, em outros (no Brasil e em outras dry cultures), sair para beber significa sair para embebedar-se. Nestes, rara- mente se aprende a beber em casa, com a refeição. No entanto, em muitas línguas, a bebida significa o elixir da vida ("eau de vie", whiskey) ou mesmo algo que tem a ver com a alma (spirit para destilados, em inglês). Complicam ainda mais as coisas, os achados de pesquisas de que o álcool pode prevenir problemas cardíacos, se usado com moderação.

Mas o que é moderação? Interpretando pesquisas semelhantes, americanos indicam quantidades de uso consideradas de pouco risco muito menores que os australianos, para quem 28 drinques por semana para homens e 14 por semana para mulheres seriam de "pouco risco" 12; nos Estados Unidos, recomendam-se 14 drinques por semana para homens e 7 por semana para mulheres 13. Assim, o artigo poderia (e deveria) ser aumentado, para abordar outros aspectos ainda tão intrigantes do uso das bebidas. Concluir-se-ia, então, que o uso de álcool, bem como o alcoolismo, podem ser vistos como doença, vício, xingo ou carma - dependendo do ponto de vista do interlocutor.

1. Reynière G. Manual dos anfitriões. São Paulo: Editora Degustar; 2002.

2. Simão MO, Kerr-Corrêa F, Dalben I, Smaira SI. Mulheres e homens alcoolistas: um estudo comparativo de fatores sociais, familiares e de evolução. Rev Bras Psiquiatr 2002; 24:121-9.

3. Fillmore KM, Hartka E, Johnstone BM, Leino MV, Motoyoshi M, Temple MT. A meta-analysis of lifecourse variation in drinking. Br J Addict 1991; 86:1221-68.

4. Kerr-Corrêa F, Dalben I, Trinca L, Simão MO, Mattos PF, Cerqueira ATAR, et al. I Levantamento do uso de álcool e de drogas e das condições gerais dos estudantes da UNESP (1998). São Paulo: Fundação Vunesp; 2001.

5. Carlini EA, Galduróz JCF, Noto AR, Nappo SA. I Levantamento domiciliar sobre o uso de drogas psicotrópicas no Brasil-2001. São Paulo: Centro Brasileiro de Informações sobre Drogas Psicotrópicas/Universidade Federal de São Paulo/Secretaria Nacional Antidrogas; 2002.

6. Wilsnack R, Wilsnack SC. Gender and alcohol individual and social perspectives. New Jersey: Rutgers Center of Alcohol Studies; 1997.

7. Wilsnack SC, Wilsnack RW. International gender and alcohol research: recent findings and future directions. Alcohol Res Health 2002; 26:245-50.

8. Cami J, Farré M. Mechanisms of disease: drug addiction. N Engl J Med 2003; 349:975-86.

9. American Psychological Association. Diagnostic and statistical manual of mental disorder (DSMIII). 3rd Ed. Washington DC: APA Press; 1980.

10. Babor TF, Higgins-Bibble JC, Saundres JB, Monteiro MG. AUDIT: teste para identificação de problemas relacionados ao uso de álcool - roteiro para uso em atenção primária. Ribeirão Preto: Faculdade de Medicina de Ribeirão Preto; 2003.

11. Kreitman N. Alcohol consumption and the prevention paradox. Br J Addict 1986; 81:353-63. 
12. National Health and Medical Research Council. Australian alcohol guidelines: health risks and benefits. Canberra: National Health and Medical Research Council/AusInfo; 2001.

13. National Institute on Alcohol Abuse and Alcoholism. The physician's guide to helping patients with alcohol problems. Bethesda: National Institute on Alcohol Abuse and Alcoholism; 1995.

\section{Beatriz Carlini Marlatt}

Instituto de Prevenção e Atenção às Drogas, Pontifícia Universidade Católica do Paraná, Curitiba, Brasil. Addictive Behaviors Research Center, University of Washington, Seattle, United States. bia@u.washington.edu
O artigo de Delma Pessanha Neves é extremamente bem-vindo, levando-se em conta o estado de indigência crônica vivenciada no Brasil, em termos de reflexão antropológica do uso intenso de álcool.

Apesar da não se referir a obras clássicas nesse campo, como o estudo antropológico Druken Comportment 1 e as excelentes pesquisas históricas do sociólogo Harry Levine 2,3,4 sobre os movimentos de temperança e sua articulação com a ética protestante e a ideologia capitalista de ordem e eficiência, o texto de Neves nos brinda com uma reflexão madura sobre as questões metodológicas que a ciência antropológica se depara ao querer estudar indivíduos e grupos sociais que se embriagam de forma sistemática.

A despeito dessas inegáveis qualidades, o texto de Neves me incomodou bastante, na medida em que - na tentativa de validar seu argumentos - ela simplifica dois processos e ignora nuances que são vitais para profissionais de outras áreas, que também se dedicam a entender o comportamento habitual de beber intensamente. Explico.

Pelo texto apresentado, tem se a nítida impressão de que epidemiólogos, sociólogos e profissionais de saúde abraçam unanimemente a noção de que aqueles que bebem pesadamente são portadores de uma doença chamada alcoolismo, definida com base em um conjunto de sinais e sintomas descritos na literatura especializada.

Isso não é verdade, para, acredito eu, benefício de todos. Para me ater somente a um desses campos profissionais, parcela significativa de profissionais de saúde de várias formações vêm cada vez mais questionando a definição do alcoolismo como doença, preferindo abraçar a noção de um comportamento aprendido e modelado socialmente, que eventualmente traz complicações na área de saúde física e de desempenho social para alguns indivíduos.
Essa nova noção tem tido por sua vez implicações gigantescas no que se diz respeito à maneira de abordar as pessoas que bebem intensamente. Ao invés de brindá-las com o rótulo de alcoolista e sugerir que eles entreguem seu destino nas mãos de um poder superior, dado sua impotência de agir de modo autônomo, esses novos profissionais trabalham de modo não rotulador, não acusador, e constroem alternativas de comportamentos de beber com base no desejo do paciente. Ainda, procuram oferecer ao paciente informações sobre seu estado de saúde física e mental que os instrumentalizem a fazer escolhas sensatas, sem no entanto impor um objetivo terapêutico rígido. Ignorar essa abordagem não tradicional, construída a partir dos anos 80 , e fortalecida desde a consolidação do movimento de redução de danos no quadro internacional, é não fazer jus à luta política e ideológica de importantes setores da nossa sociedade.

Outra simplificação, a meu ver, é a decisão de Neves de estudar alcoolistas tendo como amostra os freqüentadores dos Alcoólicos Anônimos (AA). Embora compreensível, na medida em que estuda os indivíduos baseando-se na maneira como eles próprios se percebem, respondendo assim a princípios metodológicos caros à ciência da Antropologia, a escolha de Neves acaba, de modo certamente não intencional, limitando em muito a compreensão do fenômeno da ingestão intensa e sistemática de bebidas alcoólicas.

O usuário de bebidas alcoólicas que freqüenta e se beneficia com a filosofia dos AA tem um perfil muito específico de bebedor, que responde a uma parcela diminuta de pessoas que bebem pesadamente e que se reconhecem como tendo um "problema" com bebidas. Apesar da falta de pesquisas nessa área, estima-se que somente metade daqueles que comparecem a uma primeira reunião de AA vai concordar em ir a uma segunda reunião e um proporção bem menor vai aderir ao movimento e aceitar sua ideologia. Essa baixa adesão é comum para qualquer modalidade de serviços oferecida para pessoas que bebem intensamente, não sendo de modo nenhum uma indicação de inadequação do movimento de AA. Mas para aderir aos AA é preciso ser um tipo muito singular de bebedor: alguém que aceite a rotulação de alcoolista, e se beneficie com a noção de vitimização e impotência decorrente desse rótulo.

Assim, a escolha de Neves acaba por negligenciar parcelas enormes de indivíduos que bebem muito e reconhecem seu comportamento como um problema para si e para a socieda- 
de, mas não estão dispostos a ser rotulados como portadores de uma doença progressiva, fatal e incurável, como é requerido em um dos famosos 12 Passos dos AA. Esses indivíduos vão eventualmente encontrar os profissionais de saúde que adotam abordagens alternativas como as descritas nos parágrafos anteriores, ou vão até mudar de comportamento sem nenhuma ajuda profissional, como documenta os estudos de Linda Sobell \& Mark Sobell 5, no Canadá, e o trabalho não acadêmico, mas não menos rigoroso de Anne Fletcher 6, nos Estados Unidos.

De todo modo, se de um lado há, a meu ver, necessidade de melhor trabalhar essas questões no trabalho de Neves, há também, como já apontado, muito o que celebrar em relação ao texto articulado e crítico que ela nos brinda. Que o diálogo continue, para enriquecimento de todos.

1. MacAndrew C, Edgerton R. Drunken comportment: a social explanation. Chicago: Aldine; 1969.

2. Levine HG. The discovery of addiction. Changing concepts of habitual drunkenness in America. J Stud Alcohol 1978; 39:143-73.

3. Levine HG. The alcohol problem in America: from temperance to alcoholism. Br J Addict 1984 79:109-19.

4. Levine HG. Temperance cultures: concern about alcohol problems in Nordic and English-speaking cultures. In: Edwards G, Lader M, Drummond C, editors. The nature of alcohol and drug related problems. New York: Oxford University Press; 1991.p. 16-36.

5. Sobell MB, Sobell LC. Problem drinkers - guided self-change treatment. New York: Guilford Press; 1993.

6. Fletcher AM. Sober for good - new solutions for drinking problems. New York: Houghton Mifflin Company; 2001
José A. Chaieb

Porto Alegre, Brasil j.chaieb@via-rs.net
Não obstante as dificuldades semânticas enfrentadas para o entendimento do texto, e da exígua passagem reservada para a participação de um professor de Medicina, restringirei meus comentários a apenas alguns poucos trechos que minha experiência na pesquisa em tabagismo e alcoolismo me permitem formular.

Já no título, Neves contempla um antagonismo, um dilema conceitual difícil de aceitar, pois não exibe o respaldo científico necessário para considerar-se o alcoolismo como algo que decorra de uma rotulagem vinda de fora para dentro do indivíduo como a autora sugere com a tese da "acusação". A proposição emerge de observações de caráter empírico (que se conhece por uma rápida referência feita entre parêntesis, no terceiro parágrafo da p. 8), e que pode ser resumida a afirmativa: "afinal, o alcoólico é aquele que assim se vê ou adota o ponto de vista acusatório do outro" (p. 12). Se assim fosse, o alcoolismo se excluiria da esfera médica para surgir no campo da introjeção pessoal, da rotulagem acusatória, de uma sociedade culturalmente mais ou menos complacente. Não é assim que a medicina encara a questão.

Na medicina de hoje, sabe-se que o alcoolismo é uma doença individual, cuja influência genética está bem documentada nos humanos, por meio de estudos em populações de gêmeos homozigóticos 1 onde, decorrente das várias e complexas inter-relações de genes DRD4 2 nos cromossomas 10, 11 e 123 , em que a regulação do metabolismo da álcool-dependência é feita pelos alelos ADH (desidrogenase alcoólica) e o da álcool-resistência o é pelo alelo ALDH (desidrogenase aldeídica) 4.

Assim sendo, os indivíduos não nascem alcoólatras, herdam a predisposição genética para desenvolverem o alcoolismo, que não tendo um caráter dominante como: cor dos olhos, da pele, dos pêlos e outros atributos individuais, se manifestará ou não em decorrência de fatores de natureza psicológica e ambiental. Fica óbvio que a regulação ambiental e psicológica pode ser decisiva para a manifestação do caráter álcool-dependência, haja vista que não se constitui um problema em saúde pública nos países islâmicos, onde bebidas alcoólicas não estão disponíveis. O que não exclui a herança da álcool-dependência entre tal população. Afirmações peremptórias como: " a ingestão de bebida alcoólica, mesmo a considerada abusiva, constitui um ato social", não pode ser feita sem uma clara justificativa, pois considera-se o 
alcoolismo uma doença individual. Beber é tanto um ato social como são todos os demais que caracterizam a vida em sociedade: beber, fumar, comer, dançar, conversar, discutir, namorar, negociar, competir, trabalhar... enfim, viver em sociedade. Qualquer dessas atividades exercida abusivamente, se constituirá em ato transgressivo das normas sociais, podendo acarretar danos nas mais variadas esferas.

Não concordo também com o penúltimo parágrafo da p. 11 onde se desqualifica o alcoolismo como doença, pois atribui-se-lhe o propósito desabonatório, desmoralizante. O diagnóstico, no caso, busca identificar algo anormal que vem de dentro para fora e quem o faz, o faz para melhor conhecer as causas dessa disfunção e buscar corrigi-la, usando para isso os recursos terapêuticos disponíveis num dado momento. $\mathrm{O}$ isolamento e abstinência do doente é parte necessária para sua recuperação, com o uso de drogas e a psicoterapia, pois temse o objetivo de reintegrá-lo à família e à sociedade. O alcoólatra é na concepção médica, um doente orgânico e não um produto de uma construção familiar ou social.

No último parágrafo da p. 12 há uma evidente contradição conceitual em duas afirmações: (a) “...a ingestão de bebida alcoólica, mesmo a abusiva, constitui um ato social..." (aqui é social) e (b) "essas regras são internalizadas pelo alcoólatra como demonstra sua presença fugidia no bar ou a sua solidão..." (aqui é antisocial).

Ora, se assim fosse, quem condenaria o alcoólatra que passa fugidiamente pelo bar e curte seu drama solitariamente? Que implicação social esse suposto abuso construiria?

A sociedade trata o bom alcoólatra com carinho e compreensão. Nesse caso, a sociedade é tolerante e o alcoólatra é aceito como o produto de suas frustrações, em geral amorosas, tão abordadas por poetas e cantadores de todo o mundo, por artistas e literatos e vem sempre muito bem expressa no anedotário popular, não obstante saber-se que viverão menos e sofrerão as conseqüências físicas, psíquicas e sociais de sua dependência, necessitando portanto atendimento voltado para sua proteção física e psíquica.

O mau alcoólatra, porém, pelo dano que em geral inflige à família e à sociedade, deve sofrer o isolamento indispensável para o tratamento de sua dependência química, bem como a utilização de todo o arsenal terapêutico disponível para a sua difícil, embora possível integração familiar e social.

Nas pesquisas científicas utilizam-se inúmeros critérios para a mais apurada identifica- ção do alcoólatra. Existem escalas como a C.A. G.E. que utilizou-se em nosso meio em Saúde Pública 5, bem como o hoje amplamente utilizado Índice de Adição Severa (Addiction Severity Index) 2. Essa metodologia diagnóstica pode e é aplicada em Saúde Pública ou individualmente, não com o propósito acusatório ou vexatório como foi considerado no texto, mas como instrumento de estudo que tornou possível a descoberta da origem genética da disfunção bioquímica cerebral, que ocorre em cerca de $10 \%$ da população, como muitos estudos demonstram.

Essas são as breves críticas que acho conveniente fazer sobre essa complicada e complexa apresentação, o que sem dúvida demonstra a competência, coragem e determinação da autora.

1. Heath AC, Bucholz KK, Madden PA, Dinwiddie SH, Slutske WS, Bierut LJ, et al. Genetic and environmental contributions to alcohol dependence risk in a national twin sample: consistency of findings in women and men. Psychol Med 1997; 27:1381-96.

2. Comings DE, Gonzalez N, Wu S, Gade R, Muhleman D, Saucier G, et al. Studies of the 48 bp repeat polymorphism of the DRD4 gene in impulsive, compulsive, addictive behaviors: Tourette Syndrome, ADHD, pathological gambling, and substance abuse. Am J Med Genet 1999; 88:358-68.

3. Wilhelmsen KC, Schuckit M, Smith TL, Lee JV, Segall SK, Feiler HS, et al. The search for genes related to a low-level response to alcohol determined by alcohol challenges. Alcohol Clin Exp Res 2003; 27:1041-7.

4. Mulligan CJ, Robin RW, Osier MV, Sambuughin N, Goldfarb LG, Kittles RA, et al. Allelic variation at alcohol metabolism genes (ADHIB, ADHIC, ALDH2) and alcohol dependence in American Indian population. Hum Genet 2003; 113:325-36.

5. Chaieb JA, Castellarin C. Associação tabagismoalcoolismo: introdução às grandes dependências humanas. Rev Saúde Pública 1998; 32:246-54. 


\section{Gilberto J. Paz Filho}

Departamento de Clínica Médica, Hospital de Clínicas, Universidade Federal do Paraná, Curitiba, Brasil. g.paz@uol.com.br
Segundo o DSM-IV (Diagnostic and Statistical Manual of Mental Disorders, editado pela American Psychological Association 1), os transtornos decorrentes do uso de álcool são classificados de acordo com o padrão em que a substância é utilizada. Entretanto, no artigo em debate, diversos termos são usados em referência ao ato de consumir álcool como "o beber", " $a$ embriaguez”, “o alcoolismo”, sem no entanto abordar as variâncias que envolvem o uso de álcool. O termo correto, mais abrangente, seria "transtorno por uso de álcool”, que subdividese em dependência, abuso, intoxicação e abstinência. É importante fazer tal diferenciação, pois o padrão de consumo não se assemelha, trazendo repercussões variadas. De relevância para o debate em questão, dependência deve ser diferenciada de abuso. À diferença dos critérios para dependência de substância, os critérios para abuso de substância não incluem tolerância, abstinência ou um padrão de uso compulsivo, incluindo, ao invés disso, apenas as conseqüências prejudiciais do uso repetido. O abuso de álcool, bem como a dependência, é decorrente de um padrão mal-adaptativo do seu uso. Inicialmente, o abusador pode manter-se nessa categoria por tempo indeterminado. Quando desenvolver tolerância, abstinência ou uso compulsivo, passará a preencher os critérios de dependência. Sociedades que tem apenas "embriaguez" como problema, necessariamente têm freqüência considerável de abuso de álcool, mas nem sempre de dependência. Sendo assim, o termo correto para "embriaguez" é “abuso de álcool”, e para "alcoolismo", "dependência", ambos classificados como doença. Sendo assim, o indivíduo que se "embriaga" repetidamente, ou seja, abusa do álcool sem, no entanto, desenvolver tolerância, abstinência ou compulsão, é tão doente quanto aquele que é "alcoolista”, ou seja, dependente. A utilização de termos que se enquadram na definição de acusação ("bebedores, alcoólatras, bêbados”), que não estejam entre aspas, é inadequada e é reconhecidamente cultural e nãoacadêmica. Tais termos devem ser evitados pois contribuem mais ainda para a marginalização do abusador e do dependente do álcool.

O diagnóstico dos transtornos do uso do álcool, ao contrário do que muitos podem supor, é difícil fora de um meio específico, como grupos de auto-ajuda. A isso atribuem-se os tabus sociais, que ao mesmo tempo incentivam o consumo eventual de álcool e marginalizam os abusadores e dependentes, fazendo com que esses indivíduos optem por esconder ou omitir sua situação. Sob o ponto de vista médico, depender do relato espontâneo do indivíduo quanto à sua condição leva ao subdiagnóstico da doença. Além disso, supor que um indivíduo seja abusador ou dependente com base apenas no contexto social em que está inserido é uma “acusação", ou seja, não-científica e passível de erros. Para a identificação de tais transtornos existem diversos instrumentos sob a forma de questionários, amplamente utilizados e com graus de sensibilidade, especificidade e praticidade variados 2. Dentre esses questionários, citam-se: AUDIT, TWEAK, MAST e CAGE. Cada um deles tem sua particularidade, porém todos baseiam-se nos critérios do DSM-IV. O mais prático é o CAGE, composto por quatro questões, possuindo boas sensibilidade e especificidade, podendo ser usado como método de triagem 3

Epidemiologicamente, os transtornos de uso de álcool afetam cinco vezes mais homens do que mulheres. Homens são acometidos em idade mais precoce, mas uma vez portadoras do transtorno, as mulheres têm uma progressão mais rápida da doença. Aproximadamente metade dos homens e um terço das mulheres americanas já engajaram num padrão arriscado de consumo de álcool, seja esporádico ou diário. A longo dos últimos anos, as pessoas têm iniciado o consumo de álcool cada vez mais cedo, o risco de dependência tem aumentado e o padrão de uso de álcool e dependência entre as mulheres têm se tornado semelhantes aos dos homens.

Enquanto objeto de estudo, os transtornos de uso de álcool, se não forem considerados doença, podem ser subestimados e a análise resultante, não fidedigna da realidade. Isso pode ocorrer devido ao fato de que deixarão de ser abordados aspectos referentes àqueles indivíduos que consomem álcool de maneira patológica mas que não o admitem. Por isso, deve haver o enfoque dos transtornos de uso de álcool não somente sob o ponto de vista social, psicológico e biológico, mas também patológico 4. Questionários específicos para seu diagnóstico devem ser aplicados quando uma população for estudada, a fim de corretamente identificar aqueles que são portadores da doença, evitando o vício de seleção da amostra. Sendo assim, é feito o "diagnóstico" e não a “acusação”.

1. American Psychological Association. DSM IV Manual diagnóstico e estatístico de transtornos mentais. 4a Ed. Porto Alegre: Artes Médicas; 1995.

2. National Institute of Alcohol Abuse and Alcoholism. Assessing alcohol problems: a guide for clinicians and researchers. Washington DC: $\mathrm{Na}-$ 
tional Institute of Alcohol Abuse and Alcoholism; 1992.

3. Liskow B, Campbell J, Nickel EJ, Powell BJ. Validity of the CAGE questionnaire in screening for alcohol dependence in a walk-in (triage) clinic. J Stud Alcohol 1995; 56:277-81.

4. Mersy DJ. Recognition of alcohol and substance abuse. Am Fam Physician 2003; 67:1529-32.

Marcos Baptista

Hospital Universitário Pedro Ernesto, Faculdade de Ciências Médicas, Universidade do Estado do Rio de Janeiro, Rio de Janeiro, Brasil. marcosbaptista@hotmail.com
$\mathrm{O}$ artigo tenta diferenciar, o que poderíamos dizer, duas séries sindrômicas de apreensão do uso/abuso de qualquer substância psicoativa. $\mathrm{O}$ artigo traz o álcool como exemplo porque sem dúvida tem dois principais problemas com o qual se depara a sociedade ocidental. $\mathrm{O}$ beber enquanto ato social e o beber enquanto um comportamento culturalmente atributivo (dentro da estrutura da linguagem, atribuir pode significar condensação, deslocamento ou dissociação). Devemos então considerar que o artigo dispõe-se a contribuir sob um binômio que $a$ priori considera díspare a distinção entre a categoria de acusação e diagnóstico. Trata-se, ao nosso modo de ver, de uma desconstrução e conseqüente construção de um mesmo fenômeno, isto é, a adição como se fora algo independente do sujeito, algo da ordem de um construto social.

Neste sentido, apoiamos "as reticências e resistências dos antropólogos ao reconhecimento do alcoolismo como objeto" e "a obrigatória relatividade postural", não somente pelo fato do alcoolismo poder estar ausente em algumas sociedades, mas pela constatação de que as adições são encontradas em todas as sociedades que estudarmos. Não interessa "se os antropólogos negligenciaram a questão do uso inadequado de bebidas". O que o artigo parece relevar está diretamente ligado ao comportamento inadequado, a uma construção de bordas e margens que no sentido da experiência aditiva tem pouco valor. A adição e os efeitos anômicos não nos parece nem causa, nem conseqüência, justamente porque não existe causalidade na intensidade, senão nos manteremos dentro de uma perspectiva funcionalista.

Quando analisamos o bar enquanto "espaço privilegiado de produção e reprodução de convivio rotineiro entre os homens", parece-nos que descrevemos muito mais uma síndrome, um fenômeno do que um fato, o fato é o ato de drogar-se. O fenômeno pode ser estar num bar, numa festa, num vernissage ou solitário no seu próprio quarto. Nenhuma destas averiguações é capaz de reproduzir a experiência do sujeito. Se queremos "restituir o ponto de vista do consumidor sobre o consumo do álcool e o sistema de valores subjacentes", pensamos que deveríamos perguntar-lhes o que eles têm a dizer sobre este modo particular de gozar. Perguntamos se "a impropriedade de isolar o alcoolismo como fenômeno social" não estaria ligado à nossa dificuldade de reconhecê-lo como fato social. Chamaria a atenção que nas sociedades ditas primitivas, pharmakon sempre está presente sob a forma de rito, de reconhecimento do divino ou de algum contato com o sagrado. Poderíamos dizer que pharmakon seria um contato com Deus, e isto é um fato, uma experiência da ordem do inefável, uma experiência com o Outro (no sentido hegeliano). É neste ponto de dissociação que um alcoolista ou um toxicodependente se dá conta de sua adição, isto é, no ponto onde ela falha. A adição se revela quando ela falta, falta em suprir a existência de algo que ele próprio denomina como paixão. Citando Huizenga 1 (p. 125), quando diz: "drogar-se é uma ação livre executada dentro de um 'como si' e percebida como situada fora da vida corrente, mas que pode absorver completamente o jogador, sem que ele encontre algum interesse ou obtenha algum proveito: uma ação dentro de outra ação [grifo nosso], que se estabelece em um tempo preciso e num espaço determinado, que se desenrola em uma ordem submissa a regras, que permite associações onde reina uma propensão ao mistério e à fantasia, a fim de permitir ao homem separarse do seu mundo habitual e do seu mal-estar do dia-a-dia".

Neste aspecto, não interessa se o bêbado está sozinho no bar e dorme escornado pelas calçadas. O ponto de pivotamento (pivotar tem origem no verbo francês "pivoter", cuja conjugação no particípio presente "pivotant" quer dizer por sobre pivô. Em mecânica diz-se de peça que gira em torno de um ponto fixo 2 , e de comunicação é o momento onde ele descreve sua experiência e neste sentido ela é auto-erótica. Colocaríamos esta paixão, não no nível dos psiquiatras do século XIX (Pinel, Esquirol, Magnam etc.), mas sim com base em Foucault 3 , quando ele ressalta que a experiência da droga produz uma transformação radical no segredo e no sagrado. Algo que, por vezes, não é traduzível pela linguagem. É o que se observa, quando se pede aos toxicodependentes para falar do que vivenciaram na sua viagem com a droga. Eles não conseguem descrever nada no que concerne ao afeto, mas são capazes de des- 
crever durante horas a fio o filme alucinatório que produziram a partir de seu próprio imaginário, tal qual Diógenes falava de sua experiência cínica (cinismo enquanto posição filosófica de viver).

É claro que o alcoolismo é inseparável dos alcoólatras e a desqualificação está ligada ao outro, enquanto outro interno/externo, produtor de laço social. Quanto ao Outro, que é também social, ele está ligado a uma experiência que é dita pelos toxicômanos como da ordem do para-além, entretanto, como não verificamos modificação de personalidade nesses sujeitos, pensamos que eles são os implicados no laço social. Simplesmente porque se apresentam como o produto final da ciência, ou melhor dizendo, o melhor exemplo de consumo, mercado e capitalismo, a saber: eles são fiéis aos seus objetos, eles consomem todos os dias o mesmo objeto.

Quando o artigo fala de desqualificação social do alcoolismo, é verdade que são fatos atribuídos às regras do jogo social, da mesma forma que os bêbados bem sucedidos chegam a governar países. Nenhum destes comportamentos referentes constituem histórias que falam da experiência do sujeito.

Concluiria esta abordagem crítica, dizendo que nos parece um construto científico o ato de catalogarmos as formas, as implicações, as jurisprudências e as conseqüências do comportamento relativo ao ato de drogar-se compulsivamente, entretanto, gostaria de colocar em relevo que o ato de drogar-se é um gesto psicoativo. No final, independe da opinião do outro, como também do Outro. Diógenes apregoava o caos e o suicídio, Bacos o sair de si mesmo. No final, nos parece que a questão da dependência de drogas tem muito mais relação com a dor de existir do que com o mal-estar na civilização.

1. Huizenga R. Confluences. Paris: Galimard; 1946.

2. Houaiss A. Dicionário Houaiss da língua portuguesa. Rio de Janeiro: Objetiva; 2001.

3. Foucault M. Naissance de la clinique. Paris: PUF 1978.

\section{A autora responde \\ The author replys}

Delma Pessanha

Neves

Não só para quem se lança no estudo de uma nova temática, como é o caso da autora do artigo, como também para os que a ela se dedicam há longo tempo, a proposta de debate em torno do tema privilegiado no texto, lançada pelos editores da revista, é muito oportuna e frutífera. Há uma expressão de possibilidades de desdobramentos da temática, segundo os múltiplos olhares, perspectivas e fundamentações teóricas, que no debate se intercruzam. Os comentários ao artigo ainda trazem à tona a complexidade do investimento na tentativa de estabelecer definição para o alcoolismo. Este é um fenômeno recorrentemente colocado sob suspensão e os termos de sua designação, sob iminência de (re)significação no campo acadêmico. Deste questionamento, decorrem suas múltiplas e sucessivas formas de denominação.

O debate aqui registrado também permite o conhecimento e o reconhecimento da existência de vários institutos de pesquisa e de constituição de alternativas terapêuticas, afiliadas à oferta de uma generosa lista bibliográfica, nem sempre facilmente alcançada pelos que se iniciam neste universo de estudo.

Os comentários deixam então entrever um campo temático, cujos potenciais participantes ainda estão longe do diálogo e do debate entre si. Por tais motivos, alguns dos comentários demonstram as dificuldades de comunicação com base em pontos de vista disciplinares diferenciados, mormente os que se fundamentam e se alimentam da contraposição entre disciplinas sociológicas e biológicas, neurológicas ou psiquiátricas. Neste caso, a diversidade de unidades de análise em jogo, se não considerada, transforma o diálogo em desqualificações de procedimentos. Ora, no campo interdisciplinar, ela deve ser respeitada, sob pena de inviabilizá-lo.

O debate também apresenta a grande virtude de operar como espelho para todos os participantes, no sentido de iluminar as conseqüências da definição de objetos e reflexões, assumidas pela correspondente tomada de consciência dos desdobramentos decorrentes das necessárias escolhas. Da minha parte, esta é uma das grandes contribuições a ser incorporada por este engajamento acadêmico. 
Da perspectiva da antropologia e, portanto, daquela por mim assumida no artigo, a questão que me coloquei, diante de tantas outras possíveis, inclusive algumas delas anunciadas pelos comentaristas, foi a conciliação entre a compreensão de pontos de vista. De um lado, o dos indivíduos ou grupos considerados para estudo, segundo a ênfase nas representações que constroem para seus modos e estilos de vida, de percepção e julgamento. De outro, a postura do antropólogo, que, neste caso preciso, estuda sistemas classificatórios, mas não opera diretamente no investimento constitutivo do fenômeno escolhido para reflexão. E, portanto, não investe numa definição própria para o alcoolismo, o alcoólico etc.

Não tive por intenção, com tal proposta, encantonar uma única possibilidade de estudo. Neste artigo, escolhi refletir sobre esta questão, porque tão cara aos antropólogos, diante da hegemônica perspectiva epistemológica adotada: o ponto de vista de quem vivencia o fenômeno como matéria a ser analisada. Tinha assim por objetivo, estabelecer uma provocação e um convite, também relativamente inaugurais no campo da interdisciplinaridade, estimulando o engajamento na pesquisa sobre o alcoolismo ou sobre os indivíduos portadores de dependência química.

Em outro texto 1, chamo a atenção para o tangenciamento e a secundarização do fenômeno, mesmo que ele salte aos olhos dos antropólogos por meio de entrevistas. Esta postura, no limite, leva a uma naturalização dos atos de beber qualificados como excessivos ou prejudiciais ao convívio social, especialmente entre grupos familiares e unidades de produção e trabalho.

Entretanto, destaquei que o alcoolismo (nos termos em que categorizam os entrevistados/ usuários) não pode ser considerado como fenômeno em si, porque ele está articulado a estilos de vida e se insere no quadro dos estudos sobre maneiras de beber, tão diversas quanto tem sido possível a variedade de manifestações culturais, tanto as que consagram os atos de beber, como as que os rejeitam e os proíbem (ver também os comentários de Marluce Miguel de Siqueira).

Reafirmo com as comentaristas vinculadas ao meu campo disciplinar - antropóloga e socióloga - as inúmeras perspectivas de construção de objetos de estudo. E agradeço a contribuição no sentido da reflexão sobre os modos de construção de diversas unidades de análise, que venho considerando no quadro do programa de pesquisa que coordeno, sob vínculo com o Departamento de Antropologia da Universi- dade Federal Fluminense e com o Conselho Nacional de Desenvolvimento Científico e Tecnológico 2 . Nesta temática, é fundamental assumir os limites derivados da adoção do ponto de vista exclusivo dos que se consideram alcoólatras, alcoólicos ativos ou passivos, dependentes químicos etc.

Denise Fagundes Jardim, reafirmando o caráter social dos diversos atos de beber, subsumidos a "tramas muito específicas e peculiares aos contextos", sugere um campo de estudo que amplia as possibilidades do olhar antropológico, cuja importância se destaca porque também é relativamente pouco considerado por antropólogos: os modos de expressão e definição do sofrimento que acompanha tanto o que se assumiu alcoólico, como o que resiste a aceitar esta qualificação, como os que participam da condenação, como os que são atingidos pelas conseqüências dos usos excessivos da bebida alcoólica. E, ao apontar outras possíveis questões para análise, sugere a relativização da profissão de fé do antropólogo, "principal virtude da etnografia" de colocar em relevo o "ponto de vista do nativo". Acrescentaria, então, a relevância de se considerar a diversidade desses nativos, isto é, de pontos de vista e modos de percepção e classificação do ato de beber, seja ele considerado excessivo ou não, e dos diversos agentes sociais em jogo.

Estou de pleno acordo quanto à necessária amplitude da construção de objetos de estudo, como também Margarita Antonia Villar Luis, Eurípedes Costa do Nascimento e Elizabeth S. Palatnik colocam em relevo, inclusive pela importância da valorização das especificidades da construção social de gênero. Mesmo no quadro do programa de pesquisa que coordeno, outros integrantes já se dedicaram ao entendimento do ponto de vista e das formas de intervenção das mães e esposas que reconhecem em seus filhos ou esposos, a adoção de usos inadequados da bebida alcoólica 3,4,5,6,7. Outros pesquisadores se dedicaram ao estudo dos modos de controle adotados por agentes administrativos e da gestão disciplinar sobre trabalhadores em empresas públicas e privadas. Revelaram formas de vigilância que reafirmam a suspeição, que condenam indistintamente bebedores, neste caso, nem sempre percebidos como excessivos. Contudo, mesmo assim, são qualificados por uma suposta potencialidade à criação de problemas disciplinares e à inadequação produtiva. São então lançados ao desemprego e à exclusão das redes de sociabilidade e camaradagem que asseguram o acesso aos postos de trabalho 6,8,9,10,11,12,13. Também houve investimento no estudo das formas de 
socialização, sociabilidade e controle dos abusos entre bebedores no ambiente dos bares e botequins 14; dos modos de intervenção social dos donos de bares 15,16, além do estudo de grupos de apoio e terapia 17,18,19,20. Por todos os constrangimentos que, sob essa forma de consumo, mais fortemente sobre as mulheres incidem, elas estão presentes nesses grupos, porque se vêem ou se viam como bebedoras excessivas. Também pelos mesmos motivos, nem sempre tão participativas vis-à-vis os homens que com elas compartilham a reciprocidade da auto-ajuda 20.

Essas unidades de análise revelaram aspectos importantes para o entendimento das formas de definição do uso de bebidas alcoólicas em nossa sociedade, considerada em sua segmentação ou diferenciação sócio-econômica, tais como foram ressaltados por Cecília Loreto Mariz, mas também Maria Odete Simão e Elizabeth S. Palatnik. E entre estes temas, acentuaria também a importância do investimento que Cecília Loreto Mariz vem realizando no estudo dos espaços de convivência entre fiéis de sistemas de crenças socialmente reconhecidos como evangélicos 21,22. Importantes desdobramentos em termos da concepção moral da pessoa, do indivíduo e de modos específicos de definição do alcoolismo têm sido por ela postos em relevo.

Da perspectiva de um diálogo interdisciplinar, quero chamar a atenção para a relevância da contribuição de comentaristas que incorporam o caráter social dos atos de beber. Cláudio Luiz Lottenberg, Anita Taub \& Sergio Nicastri, por um lado, Florence Kerr-Corrêa e Marluce Miguel de Siqueira, por outro, ampliam o espectro de questões sociológicas e destacam a importância do controle, especialmente o informal, que acompanha a inclusão social do uso de bebidas alcoólicas e a definição social do mais ou do menos, sempre relativa e imprecisa. Esta ambigüidade propicia a construção de formas acusatórias que incidem sobre o controle dos comportamentos, tradicionalmente objeto específico de estudo das ciências sociais. Assumindo esta premissa, os comentaristas imediatamente referidos relevam então alguns dos problemas inerentes aos modos de convívio de usuários excessivos, inclusive pela importância de sua definição como doença. E, portanto, classificada segundo modos de constituição de diagnóstico, alternativa que cria a possibilidade do apoio e do enfrentamento. Portanto, também modos socialmente construídos de controle e gestão do uso considerado abusivo e prejudicial ao usuário e àqueles que estão sob sua rede de relações.
Dessa forma, contribuem para a constituição e reconhecimento do campo temático pela exegese de termos classificatórios, pelo incessante debate no sentido de fixar provisoriamente acordos de compreensão institucionalizada. Todas as definições acentuam as conseqüências físicas do consumo intenso e prolongado de álcool e os direcionamentos das alternativas de controle: do bebedor pensado pelo seu livre arbítrio, equivalente a uma sociedade que consagra o individualismo e, assim, reconhece o alcoolismo; ou como portador de constrangimentos genéticos que tornam inviáveis esta opção e adesão a formas de consumo generalizadas na sociedade. Neste caso, o termo alcoolismo é deslocado para o senso comum. A categoria classificatória síndrome de dependência do álcool é então reveladora de modos de compreensão especializada, pautados em saberes de aquisição restrita e seletiva de $e x$ perts.

Para Florence Kerr-Corrêa, ainda estamos longe de compreender os inúmeros aspectos sociológicos do fenômeno, cabendo o reconhecimento de formas diversas de interferência e controle, como expressam termos como doença, vício, xingo, carma, todos interlocutores investindo na fixação de normas para o beber a ser expurgado ou a ser socialmente aceito.

Assumindo as vantagens e necessidades dos encontros de perspectivas, esses comentaristas sugerem então aos cientistas sociais novas questões que, incorporadas à pesquisa, podem fazer avançar a compreensão do ato de beber como social e culturalmente definido. E facilitar o diálogo da perspectiva da interdisciplinaridade. Relativizam assim as atribuídas certezas advogadas por olhares unilateralmente disciplinares, tal como também se apresenta a contribuição dos comentários apresentados por Beatriz Carlini Marlatt.

Esta postura é contrastada por comentaristas que advogam um sentido único para definição do uso inadequado do álcool, isto é, por decorrência de específica constituição orgânica ou genética. Este ponto de vista irreconhece a especificidade das unidades de análise das disciplinas vinculadas às ciências sociais. Por isso, social e anti-social representam categorias de controle moral e expressão de adequações ou inadequações a uma desejada boa sociedade.

Mesmo demonstrando assumidamente dificuldades de entendimento do ponto de vista e da retórica de outras disciplinas, José A. Chaieb empresta importante contribuição, pois que demonstra as lutas concorrenciais na definição de categorias classificatórias; os embates 
que subjazem ao entendimento dos atos abusivos da ingestão do álcool.

A concorrência pela fixação do significado mais preciso e adequado dos termos classificatórios já deixa entrever o campo de alternativas para compreensão do fenômeno. E também a pressuposição de iniciativas para hierarquização de saberes. Assim sendo, os comentaristas prestam enorme colaboração ao revelarem as inúmeras possibilidades classificatórias, inclusive a socialização de significados precisos, advindos de conhecimentos bem delimitados ou pautados sob premissas nesse plano inquestionáveis.

Em se constituindo textos a serem publicados, as contribuições ultrapassam o meu próprio proveito ou benefício epistemológico, para ampliar e precisar o conhecimento dos diversos leitores (ver especialmente o comentário de Gilberto J. Paz Filho) e mapear alternativas terapêuticas pouco conhecidas pela maior parte da população brasileira, que geralmente reconhece apenas os Alcoólicos Anônimos. E, na discordância, os que deles se evadem abrem mão das possibilidades de ajuda e de terapia diante dos sofrimentos advindos do reconhecido uso abusivo ou pesado (termo privilegiado por alguns dos comentaristas).

Enfim, gostaria de destacar que não adoto no meu texto os termos clasificatórios dos saberes constituídos no campo da medicina, pois não é esta minha unidade de análise, como destacaram alguns dos comentaristas, entre eles Maria Odete Simão e Cecília Loreto Mariz. Valorizando o ponto de vista de quem se pensa e se autodesigna alcoólico, alcoólatra, invisto no reconhecimento dos significados desses termos dos saberes populares, nessas categorias de auto e hetero percepção dos usuários. Por esta opção, considero o papel ativo dos autodesignados e dos designantes como parte constitutiva do fenômeno. E, portanto, parte do que deve ser reconhecido para que este mesmo fenômeno possa ser entendido por algumas de suas múltiplas nuances.

Valorizando uma das possibilidades dentre os pontos de vista adotados pelos antropólogos, precisando uma questão, pude facilitar para mim, inclusive por meio deste debate, a compreensão dos limites epistemológicos e metodológicos, pois uma escolha de perspectiva é sempre um ato arriscado de exclusões, nem sempre as mais adequadas. Contudo, o caráter contrastivo do uso de unidades de análise é fundamental à amplitude da compreensão. Destacaria então a instigante provocação e sugestão de pesquisa apresentadas por Marcos Baptista, cuja perspectiva é também bastante cara aos cientistas sociais, como demonstram as referências bibliográficas por ele sugeridas.

Quero me desculpar diante de cada comentarista pela impossibilidade de assumir, neste contexto, um diálogo mais direto, respeitoso da riqueza das críticas e das sugestões. Muitos deles impingem um repensar sobre as perspectivas até agora por mim adotadas. Suscitam uma retomada de temas, questões e situações empíricas de pesquisa. Ultrapassam assim a objetivação possível neste momento.

Suponho que a gratidão pelo interesse suscitado pelo artigo e pela divulgação das contribuições, inclusive pela iniciativa dos editores, pode ser expandida para todos os interessados neste tema e neste diálogo, que, apenas começando, espero possa ser desdobrado e aprofundado.

\section{Referências}

1. Neves DP. O consumo de bebidas alcoólicas: prescrições sociais. BIB - Revista Brasileira de Informação Bibliográfica em Ciências Sociais 2003; 55:73-97.

2. Neves DP. Projeto de pesquisa e planos de trabalho: o alcoolismo e a exclusão social. Niterói: Universidade Federal Fluminense/Conselho Nacional de Desenvolvimento Científico e Tecnológico; 1999.

3. Condé LR. O alcoolismo como acusação. Niterói: Programa de Pós-Graduação em Antropologia e Ciência Política, Universidade Federal Fluminense; 2001 
4. Neves DP. O lar e o bar. Incongruências da família conjugal em camadas populares. Rio de Janeiro: Conselho Nacional de Desenvolvimento Científico e Tecnológico; 2001. (Relatório de Pesquisa).

5. Santos AI. A vida familiar pelo avesso: as mulheres e a alcoolização dos homens. Semana de Ciências Sociais. Niterói: Universidade Federal Fluminense; 2002.

6. Santos AI. O trabalho, o lar e o bar. 12o Seminário de Iniciação Científica. Niterói: Universidade Federal Fluminense; 2002.

7. Santos AI. Família, alcoolismo e devoção feminina [Monografia]. Niterói; Universidade Federal Fluminense; 2003.

8. Felix GA. Alcoolização e propriedades sociais de bebedores excessivos. Trabalho apresentado na Semana de Ciências Sociais. Brasília; 2002.

9. Felix GA. A empresa e o bar: sociabilidade dos trabalhadores. 13o Seminário de Iniciação Científica. Niterói: Universidade Federal Fluminense; 2003.

10. Neves DP. Trabalho, alcoolismo e previdência social. Rio de Janeiro: Conselho Nacional de Desenvolvimento Científico e Tecnológico; 2002. (Relatório de Pesquisa).

11. Neves DP. Alcoolização e produtividade econômica. Rio de Janeiro: Conselho Nacional de Desenvolvimento Científico e Tecnológico; 2003. (Relatório de Pesquisa).

12. Tornentino AB. Trabalho e sobriedade. Semana de Ciências Sociais. Brasília; 2002.

13. Tornentino AB. A empresa e o bar: sociabilidade dos trabalhadores. 13o Seminário de Iniciação Cientifica. Niterói: Universidade Federal Fluminense; 2003.

14. Garcia AM. Os bares no contexto de um bairro popular. Niterói: Universidade Federal Fluminense/Conselho Nacional de Desenvolvimento Científico e Tecnológico; 2000.
15. Peçanha MRS. Os bares como patrimônio familiar: o bar de S. Joaquim e o bar do S. Jorge. Rio de Janeiro: Conselho Nacional de Desenvolvimento Científico e Tecnológico; 2000. (Relatório de Pesquisa).

16. Silva PF. O dono do bar e os bebedores exemplares. Rio de Janeiro: Universidade Federal Fluminense/Conselho Nacional de Desenvolvimento Científico e Tecnológico; 2000. (Relatório de Pesquisa).

17. Garcia AM. A noção do "fundo do poço" e a viabilidade dos Alcoólicos Anônimos. Niterói: Universidade Federal Fluminense/Conselho Nacional de Desenvolvimento Científico e Tecnológico; 2001.

18. Garcia AM. Alcoólicos Anônimos: conversão e abstinência terapêutica. IV Reunião de Antropologia do Mercosul. Curitiba: Universidade Federal do Paraná; 2001.

19. Garcia AM. A lógica da organização familiar no processo terapêutico dos Alcoólicos Anônimos. 23a Reunião Brasileira de Antropologia. Gramado; 2002.

20. Garcia AM."E o verbo (re)fez o homem": estudo do processo de conversão do alcoólico ativo em alcoólico passivo [Dissertação de Mestrado]. Niterói: Universidade Federal Fluminense; 2003.

21. Mariz CL. Libertação e ética: uma análise do discurso de pentecostais que se recuperaram do alcoolismo. In: Antoniazzi A, organizador. Nem anjos nem demônios: interpretações sociológicas e pentecostalismo. Petrópolis: Editora Vozes; 1994. p. 204-24.

22. Mariz CL. Alcoolismo, gênero e pentecostalismo. Religião e sociedade 1994; 16:81-93. 